\title{
Hoe kan het beter? Preventie van handelsoorlogen en geschillenbeslechting door de Wereldhandelsorganisatie
}

Citation for published version (APA):

van den Bossche, P. L. H. (2002). Hoe kan het beter? Preventie van handelsoorlogen en geschillenbeslechting door de Wereldhandelsorganisatie. P. van den Bossche. https://doi.org/10.26481/spe.20020927pb

Document status and date:

Published: 27/09/2002

DOI:

10.26481/spe.20020927pb

Document Version:

Publisher's PDF, also known as Version of record

Please check the document version of this publication:

- A submitted manuscript is the version of the article upon submission and before peer-review. There can be important differences between the submitted version and the official published version of record.

People interested in the research are advised to contact the author for the final version of the publication, or visit the DOI to the publisher's website.

- The final author version and the galley proof are versions of the publication after peer review.

- The final published version features the final layout of the paper including the volume, issue and page numbers.

Link to publication

\footnotetext{
General rights rights.

- You may freely distribute the URL identifying the publication in the public portal. please follow below link for the End User Agreement:

www.umlib.nl/taverne-license

Take down policy

If you believe that this document breaches copyright please contact us at:

repository@maastrichtuniversity.nl

providing details and we will investigate your claim.
}

Copyright and moral rights for the publications made accessible in the public portal are retained by the authors and/or other copyright owners and it is a condition of accessing publications that users recognise and abide by the legal requirements associated with these

- Users may download and print one copy of any publication from the public portal for the purpose of private study or research.

- You may not further distribute the material or use it for any profit-making activity or commercial gain

If the publication is distributed under the terms of Article 25fa of the Dutch Copyright Act, indicated by the "Taverne" license above, 


\title{
Hoe kan het beter?
}

\section{Preventie van handelsoorlogen en geschillenbeslechting door de Wereldhandelsorganisatie}

\author{
Rede in verkorte en vrije vorm uitgesproken \\ bij de aanvaarding van het ambt van \\ bijzonder hoogleraar in het internationaal handelsrecht \\ aan de Faculteit der Rechtsgeleerdheid van de Universiteit Maastricht \\ op 27 september 2002
}

door

Peter L.H. Van den Bossche 


\section{Inhoudsopgave}

$\begin{array}{ll}\text { Voorwoord } & 4\end{array}$

1. Belangrijkste kenmerken van het WTO geschillenbeslechtingssysteem 5

1.1 Een quasi-rechterlijk systeem met bijzondere kenmerken 5

1.2 Doelstelling van het systeem 5

$\begin{array}{lll}1.3 & \text { Aard van het systeem } & 6\end{array}$

1.4 Rechtsmacht 6

$\begin{array}{lll}1.5 & \text { Toegang } & 7\end{array}$

1.6 Organen 8

1.7 Procesverloop 9

$\begin{array}{lll}1.8 & \text { Naleving van uitspraken } & 10\end{array}$

$\begin{array}{lll}1.9 & \text { Samenvattend } & 10\end{array}$

2. Evaluatie van de werking van het WTO geschillenbeslechtingssysteem 11

2.1 Gebruik van het systeem 11

$\begin{array}{lll}2.2 & \text { Gebruikers van het systeem } & 12\end{array}$

2.3 Voorwerpen van geschil 13

$\begin{array}{lll}2.4 & \text { Succes van consultaties } & 14\end{array}$

2.5 Panelrapporten 15

2.6 Rapporten van de Beroepsinstantie 16

2.7 Duur van panel- en beroepsprocedures 18

$\begin{array}{lll}2.8 & \text { Naleving van de uitspraken } & 18\end{array}$

2.9 Compensatie en strafmaatregelen 20

2.10 Bijdrage tot de ontwikkeling van het WTO recht 21

$\begin{array}{lll}2.11 & \text { Samenvattend } & 22\end{array}$

3. Een beter WTO geschillenbeslechtingssysteem? 22

3.1 De Doha Ontwikkelingsronde 22

3.2 Voorstellen tot hervorming van het geschillenbeslechtingssysteem 23

3.3 Problemen en voorstellen die buiten beschouwing blijven 23

4. Samenstelling van panels $\quad 24$

4.1 Voorstel van de Europese Unie $\quad 24$

4.2 Reacties op de verdere "verrechterlijking" 25

4.3 Aantal en statuut van permanente panelleden 26

4.4 Kwalificaties van permanente panelleden 26

4.5 Onafhankelijkheid en onpartijdigheid 26

$\begin{array}{lll}4.6 & \text { Specialisatie } & 27\end{array}$

$\begin{array}{lll}4.7 & \text { Duur van panelprocedures } & 27\end{array}$

4.8 Panelleden uit ontwikkelingslanden 28

$\begin{array}{lll}4.9 & \text { Kwaliteit van panelrapporten } & 28\end{array}$

4.10 Extra kosten 28

4.11 “Alleen-zetelend panellid"? $\quad 29$

$\begin{array}{lll}4.12 & \text { Samenvattend } & 30\end{array}$

5. Maatregelen bij niet-naleving van een uitspraak $\quad 30$

5.1 Falen van het huidige mechanisme? 30 
5.2 Het voorstel van Ecuador 31

5.3 Verplichte compensatie $\quad 32$

$5.4 \quad$ Extreme middelen $\quad 32$

5.5 Collectieve strafmaatregelen 33

$\begin{array}{lll}5.6 & \text { Samenvattend } & 33\end{array}$

6. Waarschuwing met betrekking tot een verdere verbetering van het systeem

6.1 Institutionele onevenwicht 34

6.2 Noodzaak het evenwicht teherstellen 34

$\begin{array}{lll}\text { 7. Besluit } & 35\end{array}$

$\begin{array}{ll}\text { 8. Dankwoord } & 35\end{array}$ 
Mijnheer de Rector Magnificus,

Zeer gewaardeerde toehoorders,

U heeft ongetwijfeld reeds gehoord of gelezen over de "bananenoorlog", de "hormonenoorlog" en, sinds kort, de "staaloorlog" tussen de Europese Unie ${ }^{1}$ en de Verenigde Staten. Eind vorige maand kon U in alle kranten lezen dat de Europese Unie in de FSC-zaak ${ }^{2}$ voor een bedrag van \$ 4 miljard per jaar strafmaatregelen tegen de Verenigde Staten zal mogen nemen. Zoals op zoveel andere gebieden, lijkt ook op het gebied van de internationale handel de goede verstandhouding tussen de Europese Unie en de Verenigde Staten zoek. In tegenstelling tot journalisten en politici, gebruik ik echter niet graag de met emotie geladen term "handelsoorlog" om de handelsconflicten tussen de Europese Unie en de Verenigde Staten te omschrijven. Immers, een echte handelsoorlog in de zin van een ongecontroleerde escalatie van handelsvernietigende maatregelen als vergelding voor handelsvernietigende maatregelen van de tegenpartij, hebben de Europese Unie en de Verenigde Staten gelukkig tot dusver nog niet gekend. Het aantal hoogoplopende handelsruzies tussen de beide economische grootmachten is echter de laatste jaren sterk gestegen en enkele keren leek een echte handelsoorlog nabij.

Ook het aantal handelsconflicten met en tussen andere geïndustrialiseerde landen en ontwikkelingslanden is tijdens de laatste jaren aanzienlijk toegenomen. Deze toename van handelsconflicten is het gevolg van het proces van economische globalisering. De welvaart en het welzijn van staten wordt in steeds grotere mate bepaald door internationale handel in goederen en diensten. Staten zijn afhankelijk voor hun welvaart en welzijn van handel met andere staten. Tegelijkertijd kan die handel echter de werkgelegenheid in bepaalde economische sectoren bedreigen of botst vrije handel met belangrijke maatschappelijke waarden en doelstellingen, zoals de bescherming van de volksgezondheid en de bescherming van het leefmilieu. Dit brengt landen er toe om maatregelen te nemen die direct of indirect de handel beperken. In onze geglobaliseerde economie hebben dergelijke maatregelen echter onmiddellijk negatieve gevolgen voor de welvaart en het welzijn in andere landen en geven dus steeds vaker aanleiding tot conflicten.

De Wereldhandelsorganisatie (de "WTO") beschikt sinds haar oprichting in 1995 over een uniek systeem om internationale handelsgeschillen te beslechten en te voorkomen dat die geschillen ontaarden in handelsoorlogen. Deze rede handelt over dit systeem voor geschillenbeslechting. Ik bespreek eerst kort de belangrijkste kenmerken van dit systeem, evalueer dan het functioneren sinds 1995 en ga vervolgens na of, en zo ja, hoe dit systeem kan worden verbeterd. Met betrekking tot mogelijke verbeteringen, gaat de meeste aandacht uit naar twee belangrijke elementen van het systeem, de samenstelling van panels en de maatregelen om de naleving van uitspraken te bewerkstelligen. Mogelijke verbeteringen aan andere belangrijke elementen van het WTO geschillenbeslechtingssysteem kunnen binnen het tijdsbestek van deze rede jammer genoeg niet of nauwelijks aan bod komen. Alvorens te besluiten zal ik U wel nog wijzen op het gevaar dat schuilt in een verdere verbetering van het WTO geschillenbeslechtingssysteem.

\footnotetext{
Om nodeloze verwarring te vermijden, gebruik ik in deze rede steeds de benaming "Europese Unie" en niet de benamingen "Europese Gemeenschap" of "Europese Gemeenschappen". Ik merk echter op dat de "Europese Gemeenschappen", en niet de "Europese Unie", Lid zijn van de WTO.

2 United States - Tax Treatment for "Foreign Sales Corporations" ("FSC-zaak"), WT/DS108.
} 


\section{Belangrijkste kenmerken van het WTO geschillenbeslechtingssysteem}

\subsection{Een quasi-rechterlijk systeem met bijzondere kenmerken}

Het WTO systeem voor het beslechten van handelsgeschillen vindt zijn oorsprong in en is gebaseerd op het geschillenbeslechtingssysteem van de General Agreement on Tariffs and Trade van 1947. Dit oude GATT systeem was oorspronkelijk een diplomatiek geschillenbeslechtingssysteem. Bij een diplomatiek geschillenbeslechtingssysteem wordt een geschil beslecht door onderhandelingen tussen de partijen en is de oplossing van het geschil vooral afhankelijk van (en een weerspiegeling van) de onderlinge politieke, economische en militaire machtsverhoudingen tussen de partijen. In de loop van de jaren werd het oude GATT geschillenbeslechtingssysteem echter geleidelijk omgevormd tot een systeem dat heel wat kenmerken van een rechterlijk geschillenbeslechtingssysteem vertoonde. Bij een rechterlijk geschillenbeslechtingssysteem wordt een geschil beslecht door een onafhankelijke, permanente instantie - een hof of gerecht - op grond van het recht dat op het geschil van toepassing is. Toen in 1995 het WTO geschillenbeslechtingssysteem in werking trad, was dit een belangrijke stap in een reeds lange evolutie van een diplomatiek naar een rechterlijk systeem voor de beslechting van internationale handelsconflicten.

Het huidige WTO systeem heeft nog steeds enkele kenmerken van een diplomatiek geschillenbeslechtingssysteem maar is in hoofdzaak ongetwijfeld een rechterlijk systeem. Omwille van dat toch nog "onzuivere" karakter en ook omdat het systeem een aantal kenmerken van internationale arbitrage vertoont, noemt men het WTO geschillenbeslechtingssysteem vaak een quasi-rechterlijk systeem. Ik houd niet van de term "quasi-rechterlijk" maar moet toegeven dat de tijd nog niet gekomen is om de "quasi" in "quasi-rechterlijk" te laten vallen.

Het WTO systeem voor het beslechten van handelsgeschillen is uitgewerkt in het Memorandum van overeenstemming inzake de regels en procedures betreffende de beslechting van geschillen, of kort het Memorandum over Geschillenbeslechting. Dit Memorandum makt deel uit van de Marrakesh Overeenkomst tot oprichting van de Wereldhandelsorganisatie. ${ }^{3}$ Het WTO geschillenbeslechtingssysteem onderscheidt zich in menig opzicht van andere internationale systemen voor het beslechten van geschillen tussen staten, zoals het Internationaal Gerechtshof en het Internationaal Zeerechttribunaal. Laten we wat dieper ingaan op de belangrijkste, bijzondere kenmerken van het WTO geschillenbeslechtingsysteem, en vooral op de doelstelling en aard van het systeem, de rechtsmacht van en toegang tot het systeem, de organen van het systeem, het procesverloop en het mechanisme om de correcte naleving van uitspraken te bewerkstelligen.

\subsection{Doelstelling van het systeem}

Het is van wezenlijk belang voor het effectief functioneren van de WTO en het bewaren van een juist evenwicht tussen de rechten en plichten van Leden dat geschillen betreffende die rechten en plichten snel en in overeenstemming met het WTO recht beslecht worden. De doelstelling van het WTO geschillenbeslechtingssysteem is, aldus artikel 3.7 van het

3 Bijlage 2 bij de Marrakesh Overeenkomst. Een Nederlandstalige tekst van het Memorandum over Geschillenbeslechting werd gepubliceerd in het Publicatieblad van de Europese Gemeenschappen, L 336, 23 december 1994, p. 234-250. 
Memorandum over Geschillenbeslechting, een "positieve oplossing" voor een geschil te bereiken. Het geschillenbeslechtingssysteem dient ter bescherming van de rechten en plichten van WTO Leden en ter verheldering van de bepalingen van de WTO verdragen. Het geschillenbeslechtingssysteem draagt aldus in belangrijke mate bij tot de zekerheid en voorspelbaarheid van de regels van het wereldhandelssysteem.

Hoewel het geschillenbeslechtingssysteem ter verheldering van de bepalingen van de WTO verdragen dient, verbiedt het Memorandum over Geschillenbeslechting uitdrukkelijk dat het geschillenbeslechtingssysteem iets aan de rechten en plichten van WTO Leden zou toevoegen of afdoen. Een dergelijke uitdrukkelijke waarschuwing tegen judicial activism is ongebruikelijk in de oprichtingsakte van een internationaal tribunaal en weerspiegelt ongetwijfeld de vrees bij de Leden voor wat men in het Frans zo mooi le gouvernement des juges noemt. De grens tussen het verhelderen van bepalingen en het wijzigen van die bepalingen is echter niet altijd even scherp en de partij bij een geschil die in het ongelijk wordt gesteld zal al vlug beweren dat die grens werd overschreden.

\subsection{Aard van het systeem}

Het WTO geschillenbeslechtingssysteem is een multilateraal geschillenbeslechtingssysteem. De drijvende kracht achter de totstandbrenging van dit systeem was de onvrede bij vele landen over het optreden van de Verenigde Staten, dat vaak unilateraal bepaalde of een maatregel van een ander land al dan niet in strijd was met het internationaal handelsrecht en vervolgens unilateraal strafmaatregelen tegen het betrokken land nam. Krachtens artikel 23 van het Memorandum over Geschillenbeslechting is het aan Leden van de WTO niet langer toegestaan om unilateraal vast te stellen of er al dan niet sprake is van een schending van de WTO verdragen. Zulke vaststelling kan enkel door het geschillenbeslechtingssysteem worden gedaan.

Verder moet met betrekking tot de aard van het WTO geschillenbeslechtingssysteem worden opgemerkt dat dit systeem er uitdrukkelijk de voorkeur aan geeft dat partijen het geschil niet voorleggen aan de (quasi-)rechterlijke organen van het systeem, maar, door onderhandelingen, ook wel consultaties genoemd, komen tot een wederzijds aanvaardbare oplossing voor het geschil. Enkel als dat niet mogelijk is, kan en mag een geschil worden voorgelegd aan de (quasi-)rechterlijke organen van het systeem. Bij andere internationale geschillenbeslechtingssystemen ontbreekt een dergelijke uitdrukkelijke verplichting om steeds eerst te proberen door onderhandelingen tot een minnelijke schikking te komen.

\subsection{Rechtsmacht}

Het WTO geschillenbeslechtingssysteem is bevoegd voor alle geschillen met betrekking tot de zogenoemde "vermelde overeenkomsten", d.i. 18 van de 20 momenteel van kracht zijnde WTO verdragen. De reikwijdte van de rechtsmacht van het WTO geschillenbeslechtingssysteem is dan ook groot. Het omvat geschillen over handel in goederen en diensten en de bescherming van intellectuele eigendomsrechten. Nog opmerkelijker dan de reikwijdte is echter de aard van de rechtsmacht. De rechtsmacht van het WTO geschillenbeslechtingssysteem is dwingend. Door lid te worden van de WTO onderwerpen de Leden zich automatisch aan de rechtsmacht van het WTO geschillenbeslechtingssysteem. Door haar dwingende rechtsmacht onderscheidt het WTO geschillenbeslechtingssysteem zich van andere internationale systemen voor het beslechten 
van geschillen tussen Staten. Het Internationaal Gerechtshof, bijvoorbeeld, heeft geen algemene bindende rechtsmacht.

De rechtsmacht van het WTO geschillenbeslechtingssysteem is niet alleen dwingend, de rechtsmacht is ook exclusief. Geschillen met betrekking tot de WTO verdragen mogen krachtens het al vermelde artikel 23 van het Memorandum over Geschillenbeslechting enkel door het WTO geschillenbeslechtingssysteem worden beslecht. Tenslotte moet worden opgemerkt dat het WTO geschillenbeslechtingssysteem, in tegenstelling tot bijvoorbeeld het Internationaal Gerechtshof, enkel een contentieuze en geen adviserende rechtsmacht heeft. Men kan met andere woorden het WTO geschillenbeslechtingssysteem niet om advies vragen over de correcte interpretatie van een bepaling van de WTO verdragen. Men kan enkel beroep doen op het systeem om geschillen met andere Leden te beslechten.

\subsection{Toegang}

Enkel de 144 Leden van de WTO kunnen een beroep doen op het WTO geschillenbeslechtingssysteem. Staten die geen lid zijn van de WTO en internationale organisaties hebben geen toegang tot het systeem. Ook particulieren, zoals $U$ en ik, ondernemingen, zoals Microsoft en Heineken, en niet-gouvernementele organisaties, zoals Greenpeace en de Consumentenbond, kunnen geen beroep doen op het WTO geschillenbeslechtingssysteem. Het moet echter worden opgemerkt dat een geschil vaak door een WTO Lid bij het WTO geschillenbeslechtingssysteem aanhangig wordt gemaakt op aandringen van, en soms onder zware druk van, grote ondernemingen en belangenorganisaties. Een mooi voorbeeld daarvan is de beruchte Bananen-zaak ${ }^{4}$ waarin de Amerikaanse bananenreus Chiquita een centrale rol heeft gespeeld. Ondernemingen en belangenorganisaties met politieke invloed hebben indirect toegang tot het WTO geschillenbeslechtingssysteem. De Verenigde Staten en de Europese Unie hebben uitgewerkte procedures met betrekking tot het gunnen van deze indirecte toegang tot het WTO geschillenbeslechtingssysteem.

Net als bij andere internationale systemen voor geschillenbeslechting, kan een WTO Lid beroep doen op het WTO geschillenbeslechtingssysteem indien dat Lid de schending van een bepaling van één van de WTO verdragen aanklaagt. Het is echter specifiek voor het WTO systeem dat een Lid ook beroep kan doen op het WTO geschillenbeslechtingssysteem wanneer dat Lid aanklaagt dat een handelsvoordeel dat voorspruit uit één van de WTO verdragen wordt tenietgedaan of uitgehold, ongeacht of dat tenietdoen of uithollen het gevolg is van een schending van het WTO recht. Het WTO geschillenbeslechtingssysteem maakt aldus een onderscheid tussen "schendingsklachten" en "niet-schendingsklachten". Hoewel de overgrote meerderheid van klachten schendingsklachten zijn, wordt er af en toe een klacht die niet gebaseerd is op een schending van het WTO recht aanhangig gemaakt. Tot dusver is onder het WTO geschillenbeslechtingssysteem een dergelijke klacht nog nooit succesvol geweest.

\footnotetext{
4 European Communities - Regime for the Importation, Sale and Distribution of Bananas ("Bananen-zaak"), WT/DS27.

5 Zie o.a. artikel XXIII van de GATT 1994 en artikel 26 van het Memorandum over Geschillenbeslechting.
} 
Het WTO geschillenbeslechtingssysteem heeft zowel politieke als rechterlijke en quasirechterlijke organen. Hoewel de eigenlijke beslechting van geschillen wordt overgelaten aan onafhankelijke rechterlijke en quasi-rechterlijke organen, de ad hoc panels en de Beroepsinstantie, spelen politieke organen, en in het bijzonder het Orgaan voor Geschillenbeslechting, nog steeds een rol bij het beslechten van geschillen. Het Orgaan voor Geschillenbeslechting, dat bestaat uit vertegenwoordigers van alle WTO Leden, beslist over de vorming van de panels die een geschil beslechten. Het moet de uitspraken van panels en de Beroepsinstantie goedkeuren alvorens deze uitspraken juridisch bindend worden en moet in geval van niet-naleving van de uitspraak haar machtiging geven voor het nemen van strafmaatregelen. Toch is de invloed van het Orgaan voor Geschillenbeslechting op het proces van geschillenbeslechting beperkt en eerder symbolisch. Dat is het gevolg van het feit dat de voornoemde beslissingen door het Orgaan bij omgekeerde consensus worden genomen. Dit betekent dat een voorgestelde beslissing wordt genomen tenzij er onder de Leden een consensus bestaat om die beslissing niet te nemen. Het is onwaarschijnlijk dat het Lid dat voorstelt een bepaalde beslissing te nemen (bijvoorbeeld de vorming van een panel) zich vervolgens zou aansluiten bij een consensus om die beslissing niet te nemen. De beslissingen van het Orgaan voor Geschillenbeslechting over de vorming van een panel, de goedkeuring van uitspraken en de machtiging voor het nemen van strafmaatregelen zijn dan ook quasiautomatische beslissingen.

Zoals nog andere aspecten van het geschillenbeslechtingssysteem is de inmenging van de politieke arm van de WTO een erfenis uit een pre-WTO verleden waarin het geschillenbeslechtingssysteem nog een diplomatiek geschillenbeslechtingssysteem was. Het WTO geschillenbeslechtingssysteem onderscheidt zich van andere internationale systemen voor geschillenbeslechting, zoals het Internationaal Gerechtshof of het Internationaal Zeerechttribunaal, door de rol die de politieke arm van de WTO nog vervult in het kader van de geschillenbeslechting. Hoewel soms bekritiseerd en vaak slecht begrepen, heeft de huidige betrokkenheid bij geschillenbeslechting van de politieke arm van de WTO toch een overwegend positieve impact op de werking van het systeem. Deze betrokkenheid waarborgt dat alle Leden steeds op de hoogte zijn van het bestaan en het verloop van geschillen tussen Leden. Bovendien biedt deze betrokkenheid Leden de kans om op een gestructureerde manier uiting te geven aan hun instemming met of afkeuring van de manier waarop geschillen worden beslecht.

Zoals reeds opgemerkt, gebeurt de beslechting van geschillen echter niet door de politieke organen van de WTO, maar door ad hoc panels en de Beroepsinstantie. De panels zijn geen permanente organen. Zij worden op verzoek van de klager door het Orgaan voor Geschillenbeslechting gevormd en bestaan maar zolang als nodig is om het geschil te beslechten. Na de vorming van het panel, is het aan de partijen bij het geschil om te beslissen over de samenstelling van het panel. Indien de partijen bij het geschil er niet in slagen binnen 20 dagen na de vorming van het panel een akkoord te bereiken over de samenstelling van het panel, dan kan één van de partijen de Directeur-generaal van de WTO vragen om over de samenstelling van het panel te beslissen. Van deze laatste mogelijkheid wordt steeds gebruik gemaakt omdat de partijen het over de samenstelling niet eens kunnen worden. Panels bestaan vaak uit ambtenaren en diplomaten van bij het geschil niet betrokken Leden maar ook academici en advocaten kunnen in panels zetelen. Panels zijn quasi-rechterlijke organen die veel kenmerken van een internationaal arbitragetribunaal vertonen. 
In tegenstelling tot panels, is de Beroepsinstantie - de Appellate Body - wel een rechterlijk orgaan. Achter deze weinigzeggende benaming gaat een internationaal hof voor handelsconflicten schuil. Dit hoogste rechterlijke orgaan van de WTO bestaat uit zeven rechters - "leden" genoemd - die gekozen worden door het Orgaan voor Geschillenbeslechting voor maximum twee termijnen van vier jaar. De samenstelling van de Beroepsinstantie weerspiegelt de verscheidenheid van de Leden van de WTO en bestaat momenteel uit vier leden uit geïndustrialiseerde landen (Italië, Verenigde Staten, Japan en Australië) en drie leden uit ontwikkelingslanden (India, Brazilië en Egypte). De Beroepsinstantie neemt enkel kennis van op juridische gronden gebaseerde beroepen tegen uitspraken van panels. In vergelijking met het Internationaal Gerechtshof, dat 18 rechters telt, en het Internationaal Zeerechttribunaal, dat 21 rechters telt, is de Beroepsinstantie klein van omvang. Bovendien beslist de Beroepsinstantie over een beroep nooit in plenum maar steeds in een kamer van drie leden.

\subsection{Procesverloop}

Ook wat het procesverloop betreft onderscheidt het WTO geschillenbeslechtingssysteem zich van andere internationale systemen voor geschillenbeslechting.

Ten eerste mag worden gewezen op het feit dat het WTO systeem vereist dat de partijen altijd eerst proberen via diplomatieke onderhandelingen tot een minnelijke schikking voor het geschil te komen. Slechts als die consultaties binnen de voorgeschreven termijn niet succesvol zijn, kan de klager de vorming van een panel vragen.

Ten tweede heeft het WTO geschillenbeslechtingssysteem een beroepsprocedure. Andere internationale geschillenbeslechtingssystemen, zoals het Internationaal Gerechtshof en het Internationaal Zeerechttribunaal, hebben geen beroepsprocedure.

Ten derde is de procedure voor panels en de beroepsprocedure aan strikte tijdslimieten gebonden. De procedure voor de Beroepsinstantie bijvoorbeeld mag in geen geval langer dan 90 dagen duren. Deze tijdslimiet gaat in op de dag van het instellen van het beroep en stopt op de dag van de verspreiding van de einduitspraak in de drie officiële talen van de WTO. Geen enkel internationaal hof of tribunaal werkt onder een dergelijke tijdsdruk. Zulke tijdslimieten zijn zowel voor de (quasi-)rechterlijke organen van de WTO als voor de partijen, en in het bijzonder dan ontwikkelingslanden, een zware belasting.

Ten vierde moet worden gewezen op het besloten karakter van zowel de panelprocedure als de beroepsprocedure. Alle processtukken zijn vertrouwelijk en niet toegankelijk voor de burger of WTO Leden die niet direct bij het geschil betrokken zijn. Het staat een partij vrij om zijn eigen standpunt openbaar te maken maar slechts heel weinig Leden doen dat ook. De hoorzittingen van de panels en de Beroepsinstantie vinden altijd plaats achter gesloten deuren. De uitspraken van panels en de Beroepsinstantie, vervat in zogenoemde panelrapporten en rapporten van de Beroepsinstantie, zijn echter wel publieke documenten van zodra zij aan alle Leden van de WTO zijn toegezonden. Het geheime karakter van de procedures is een erfenis van het oude GATT geschillenbeslechtingssysteem dat, zoals reeds vermeld, in oorsprong een diplomatiek systeem voor geschillenbeslechting was. Diplomatieke geschillenbeslechting schuwt de openbaarheid en werkt best achter gesloten deuren. De hoorzittingen van zuiver rechterlijke geschillenbeslechtingssystemen, zoals het Internationale Gerechtshof en het Internationaal Zeerechttribunaal, zijn in de regel voor eenieder toegankelijk. 


\subsection{Naleving van uitspraken}

Tenslotte verschilt het WTO geschillenbeslechtingssysteem van andere internationale systemen voor geschillenbeslechting door te voorzien in een uitgewerkt mechanisme om de naleving van uitspraken te verkrijgen. ${ }^{6}$ Het Orgaan voor Geschillenbeslechting houdt toezicht op de tenuitvoerlegging van de uitspraken van panels en de Beroepsinstantie. Een WTO Lid dat haar wetgeving of praktijk krachtens een uitspraak moet wijzigen, is verplicht regelmatig hieromtrent verslag uit te brengen bij het Orgaan voor Geschillenbeslechting. Wanneer $n a$ het verstrijken van een redelijke termijn voor de tenuitvoerlegging van de uitspraak, het Lid haar wetgeving of praktijk niet in overeenstemming met het WTO recht heeft gebracht en de partijen het niet eens kunnen worden over een tijdelijke compensatie, dan kan de oorspronkelijke klager het Orgaan voor Geschillenbeslechting machtiging vragen om strafmaatregelen tegen het in gebreke blijvende Lid te mogen nemen. Zoals reeds vermeld, beslist het Orgaan voor Geschillenbeslechting over de machtiging bij omgekeerde consensus en machtiging wordt aldus quasi-automatisch verleend. De strafmaatregelen bestaan uit de opschorting van concessies of andere verplichtingen ten bedrage van "schade" in "tenietgedane" of "uitgeholde" handelsvoordelen die de oorspronkelijke klager lijdt. De strafmaatregelen nemen meestal de vorm aan van een belangrijke verhoging van de invoerrechten op producten van het veroordeelde Lid. De maatregelen blijven van kracht zolang het Lid geen uitvoering geeft aan de uitspraak van het panel of de Beroepsinstantie. De strafmaatregelen zijn niet bedoeld als boete maar als een middel om het in gebreke blijvende Lid er toe te brengen de uitspraak na te leven.

Het WTO geschillenbeslechtingssysteem voorziet in bijzondere procedures om allerlei geschillen die bij de naleving van een uitspraak kunnen ontstaan te beslechten. Het WTO systeem voorziet zo in arbitrage procedures om te bepalen wat een redelijke termijn voor de tenuitvoerlegging van een uitspraak is of hoe zwaar de strafmaatregelen bij niettenuitvoerlegging mogen zijn. Het systeem voorziet ook in een versnelde panelprocedure om de rechtmatigheid van uitvoeringsmaatregelen te toetsen. Geen enkel ander internationaal systeem voor geschillenbeslechting beschikt over een dusdanig uitgewerkt mechanisme om de snelle en correcte naleving van uitspraken te bewerkstelligen.

\subsection{Samenvattend}

Het WTO geschillenbeslechtingssysteem is in menig opzicht een uniek systeem voor de beslechting van internationale geschillen. Het onderscheidt zich op belangrijke punten van andere internationale geschillenbeslechtingssystemen, zoals het Internationaal Gerechtshof of het Internationaal Zeerechttribunaal. In tegenstelling tot deze systemen, heeft het WTO geschillenbeslechtingssysteem een verplichte en exclusieve rechtsmacht, voorziet het in de mogelijkheid beroep aan te tekenen en heeft het een uitgewerkt mechanisme om de naleving van uitspraken te realiseren. Het WTO geschillenbeslechtingssysteem vertoont ook nog sporen van een diplomatiek geschillenbeslechtingssysteem. De verplichte consultaties, de aard en de samenstelling van panels en de rol van het politieke Orgaan voor Geschillenbeslechting tonen aan dat het WTO geschillenbeslechtingssysteem geen klassiek rechterlijk geschillenbeslechtingssysteem, zoals het Internationaal Gerechtshof, is. Het is een quasirechterlijk systeem met bijzondere kenmerken.

${ }_{6} \quad$ Vgl. met artikel 94, lid 3 van het Handvest van de Verenigde Naties. 


\section{Evaluatie van de werking van het WTO geschillenbeslechtingssysteem}

Het WTO geschillenbeslechtingssysteem, zoals hierboven beschreven, trad in werking op 1 januari 1995 en functioneert dus bijna acht jaar. De vraag rijst of dit systeem naar behoren heeft gewerkt. Het evalueren van de werking van het WTO geschillenbeslechtingssysteem is echter geen eenvoudige taak. De volgende evaluatie is gebaseerd op aantal, veelal kwantificeerbare, aspecten van het systeem, en in het bijzonder naar het aantal aanhangig gemaakte geschillen, de gebruikers van het systeem, de onderwerpen van geschil, het succes van consultaties, de panelrapporten, de rapporten van de Beroepsinstantie, de duur van panelen beroepsprocedures, de naleving van de uitspraken, de strafmaatregelen genomen wegens niet-naleving van uitspraken, en, tenslotte, de bijdrage van het systeem aan de ontwikkeling van het WTO recht.

\subsection{Gebruik van het systeem}

Het WTO geschillenbeslechtingssysteem heeft zich in korte tijd ontpopt tot het meest gebruikte systeem voor internationale geschillenbeslechting. Sinds 1995 hebben WTO Leden 262 geschillen bij het systeem aanhangig gemaakt. ${ }^{7}$ Tijdens dezelfde periode van bijna acht jaar werden er bij het Internationaal Gerechtshof 31 zaken en bij het Internationaal Zeerechttribunaal 10 zaken aanhangig gemaakt. ${ }^{8}$ Met uitzondering van 1995, lag het aantal aanhangig gemaakte geschillen tijdens de eerste jaren van het systeem tussen 42 en 46 geschillen per jaar. Daarna is het aantal aanhangig gemaakte geschillen teruggevallen tot ongeveer 30 per jaar. De voorlopige cijfers voor 2002 bevestigen deze trend. Het hogere aantal geschillen tijdens de eerste jaren van het WTO geschillenbeslechtingssysteem kan worden verklaard door het feit dat men tijdens de laatste jaren van de oude GATT er de voorkeur aangaf te wachten met het aanhangig maken van een geschil tot het nieuwe, verbeterde WTO geschillenbeslechtingssysteem beschikbaar zou zijn.

7 De ruwe data gebruikt voor deze rede komen, tenzij anders vermeld, uit WT/DS/OV/8 van 9 augustus 2002, het laatst beschikbare rapport van het WTO Secretariaat over de stand van WTO geschillenbeslechting. De data in dit rapport betreffen de periode van 1 januari 1995 tot en met 31 juli 2002. Dit rapport is beschikbaar op de WTO website, www.wto.org.

8 Zie http://www.icj-cij.org/icjwww/idecisions.htm voor het Internationaal Gerechtshof en http://www.itlos.org/start2 en.html voor het Internationaal Zeerechttribunaal. 


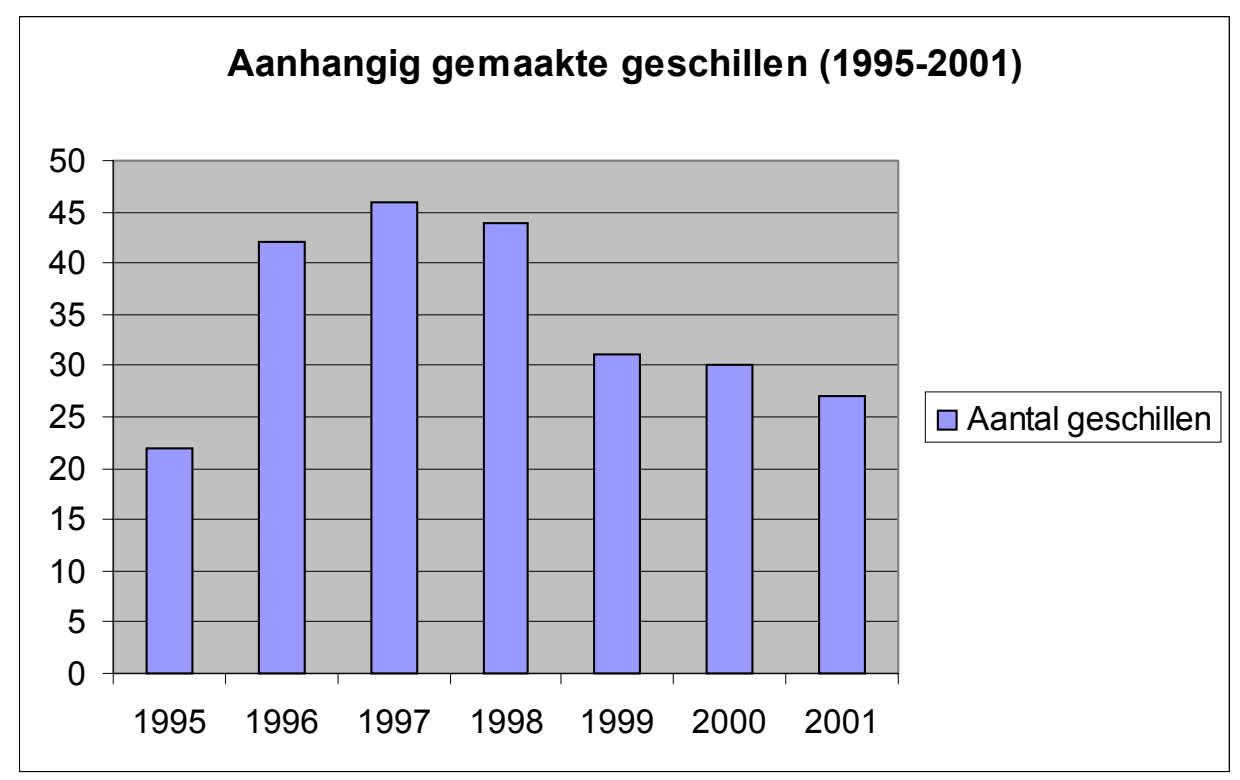

\subsection{Gebruikers van het systeem}

Zowel geïndustrialiseerde landen als ontwikkelingslanden hebben sinds 1995 veelvuldig gebruik gemaakt van het WTO geschillenbeslechtingssysteem. Met uitzondering van 1997 en 1998 waren de ontwikkelingslanden, als groep, steeds de grootste gebruikers van het systeem. In 2001 werden de ontwikkelingslanden zelfs veruit de grootste gebruikers. De voorlopige cijfers voor 2002 geven aan dat ontwikkelingslanden ook dit jaar de grootste gebruikers van het systeem zijn.

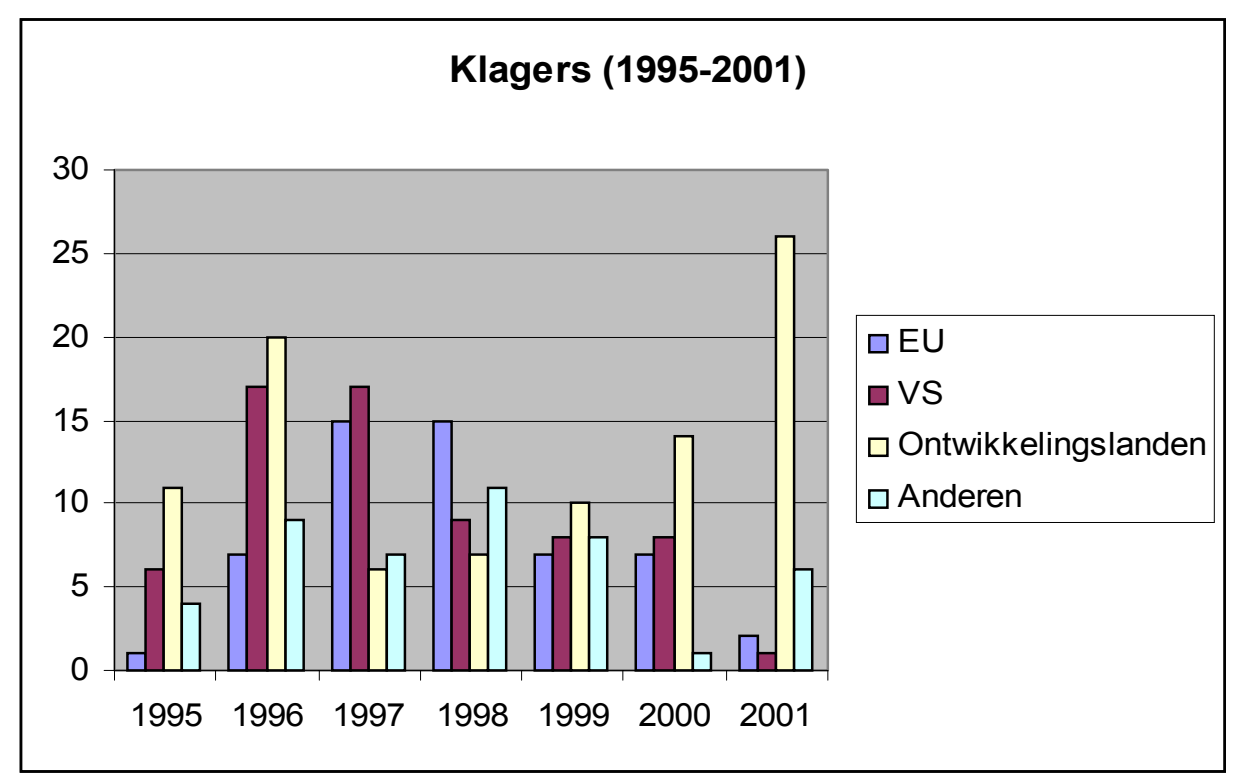

Het zal U niet verbazen dat tijdens de periode van 1995 tot 2001 de Verenigde Staten meer dan enige ander Lid gebruik heeft gemaakt van het geschillenbeslechtingssysteem. De Verenigde Staten hebben tijdens deze periode 66 geschillen aanhangig gemaakt. Tijdens dezelfde periode was de Europese Unie klager in 54 geschillen. De meest actieve gebruikers van het geschillenbeslechtingssysteem bij de ontwikkelingslanden waren India en Brazilië. 
Ontwikkelingslanden hebben zowel geschillen met geïndustrialiseerde landen als geschillen met andere ontwikkelingslanden bij het systeem aanhangig gemaakt.

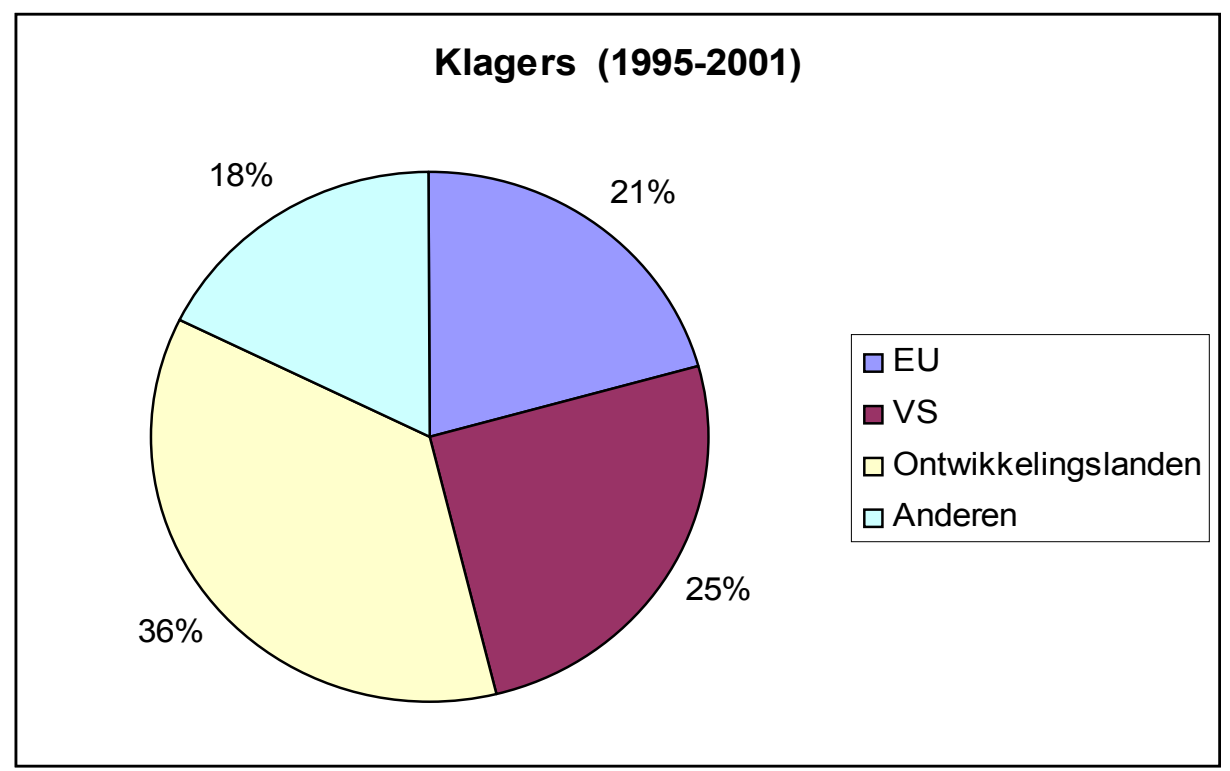

Het is opmerkelijk dat zowel de Europese Unie als de Verenigde Staten sinds 2001 veel minder geschillen aanhangig hebben gemaakt terwijl het aantal geschillen aanhangig gemaakt door ontwikkelingslanden en andere geïndustrialiseerde landen sterk is gestegen. Vooral het aantal geschillen tussen ontwikkelingslanden is behoorlijk gestegen. Eveneens opmerkelijk doch niet zo verwonderlijk is dat geen enkel van de 30 Minst-ontwikkelde-landen die Lid zijn van de WTO tot dusver een geschil aanhangig heeft gemaakt. Voor deze ontwikkelingslanden is de drempel dus blijkbaar nog te hoog.

Tijdens de periode van 1995 tot 2001 waren de verweerders in de meeste geschillen ontwikkelingslanden. In vele van die geschillen waren zowel de verweerders als de klagers ontwikkelingslanden. Zoals vermeld hebben ontwikkelingslanden het WTO systeem vaak gebruikt om handelsgeschillen met andere ontwikkelingslanden te beslechten. De Verenigde Staten was het Lid wiens wetgeving of handelspraktijk het vaakst werd aangeklaagd. In één vierde van alle geschillen was de Verenigde Staten verweerder. In één vijfde van de geschillen viel die eer te beurt aan de Europese Unie. ${ }^{9}$ Bij de ontwikkelingslanden was vooral Argentinië, India en Brazilië noodgedwongen actief als verweerder. In geen enkel geschil tot dusver was de verweerder een Minst-ontwikkeld-land. Artikel 24 van het Memorandum over Geschillenbeslechting roept de Leden op om te handelen met de nodige terughoudendheid bij het aanhangig maken van geschillen met minst-ontwikkelde landen. Hebben de Leden aan deze oproep gevolg gegeven of waren de handelsbelangen die in geschillen met minstontwikkelde landen op het spel stonden te gering om een beroep op het WTO geschillenbeslechtingssysteem te rechtvaardigen?

\subsection{Voorwerpen van geschil}

De maatregelen die tijdens de laatste acht jaar het voorwerp waren van WTO geschillenbeslechting zijn zeer verscheiden van aard. Over de gehele periode genomen, waren

$9 \quad$ Inclusief klachten tegen maatregelen van Lidstaten van de Europese Unie. 
anti-dumping maatregelen het meest frequent het voorwerp van WTO geschillenbeslechting. Echter ook invoerlicenties, maatregelen betreffende intellectuele eigendomsrechten, vrijwaringsmaatregelen, technische handelsbelemmeringen, sanitaire en fytosanitaire maatregelen, subsidies, compenserende maatregelen, maatregelen die de handel in diensten raken, binnenlandse belastingen en kwantitatieve invoerbeperkingen zijn meerdere malen het voorwerp geweest van WTO geschillenbeslechting.

Een aantal geschillen betrof maatschappelijk en politiek gevoelige onderwerpen, zoals de bescherming van de volksgezondheid (in bijvoorbeeld de Hormonen-zaak ${ }^{10}$ en de Asbestoszaak $^{11}$ ), de bescherming van het milieu (in bijvoorbeeld de Benzine-zaak ${ }^{12}$ en de Garnalenzaak $^{13}$ ) en het buitenlands (veiligheids)beleid (in bijvoorbeeld de Helms/Burton-zaak ${ }^{14}$ en de Havana Club-zaak): Deze geschillen deden vragen en problemen rijzen die het handelsbeleid en -recht ver overstijgen. Het is echter gebleken dat ook voor deze moeilijke geschillen het WTO geschillenbeslechtingssysteem heeft gewerkt. Enkel in de Helms/Burton-zaak, een geschil tussen de Verenigde Staten en de Europese Unie over Amerikaanse sancties voor bedrijven die zaken doen met Cuba, heeft de Verenigde Staten betoogd dat het geschillenbeslechtingssysteem niet bevoegd was om dat geschil te beslechten. Dit standpunt had tot een ernstige institutionele crisis kunnen leiden maar de Verenigde Staten en de Europese Unie hebben ervoor gekozen de zaak niet op de spits te drijven en een politiek akkoord na te streven.

Het veelvuldige gebruik van het WTO geschillenbeslechtingssysteem door zowel geïndustrialiseerde als ontwikkelingslanden alsmede het gebruik van dit systeem om politiek gevoelige geschillen te beslechten vormen een bewijs van het vertrouwen dat WTO Leden hebben in het geschillenbeslechtingssysteem.

\subsection{Succes van consultaties}

Zoals hierboven uiteengezet, geeft het WTO geschillenbeslechtingssysteem er de voorkeur aan dat partijen het geschil niet voorleggen aan de (quasi-)rechterlijke organen van het systeem, maar, door onderhandelingen komen tot een minnelijke schikking voor het geschil. Hoewel de klagende partij na 60 dagen vruchteloze consultaties de vorming van een panel kan vragen, geeft de klagende partij onderhandelingen vaak veel meer tijd om tot een wederzijds aanvaardbare oplossing te leiden. Van de 262 tot dusver aanhangig gemaakte geschillen, wordt op dit moment in 95 geschillen, of 36 procent, nog steeds tussen de partijen onderhandeld. ${ }^{15}$ In 60 geschillen, of 23 procent van aanhangig gemaakte geschillen, zijn partijen erin geslaagd om via onderhandelingen het geschil op minnelijke wijze te beslechten. ${ }^{16}$ In 107 geschillen, of 41 procent, was dat niet mogelijk en werd het geschil aan

10 EC Measures Concerning Meat and Meat Products (Hormones) ("Hormonen-zaak"), WT/DS26, WT/DS48.

11 European Communities - Measures Affecting Asbestos and Asbestos-Containing Products ("Asbestos-zaak"), WT/DS135.

12 United States - Standards for Reformulated and Conventional Gasoline ("Benzine-zaak"), WT/DS2.

13 United States - Import Prohibition of Certain Shrimp and Shrimp Products ("Garnalen-zaak"), WT/DS58.

14 United States - The Cuban Liberty and Democratic Solidarity Act, ("Helms/Burton-zaak"), WT/DS38.

15 Het moet echter worden opgemerkt dat de intensiteit van deze onderhandelingen sterk verschilt van geschil tot geschil.

16 In 37 geschillen werd een "mutually agreed solution" bereikt terwijl 23 andere geschillen op andere minnelijke wijze werden beslecht. 
een panel voorgelegd. ${ }^{17}$ Het is opmerkelijk dat bijna één vierde van de geschillen op minnelijke wijze kon worden beslecht.

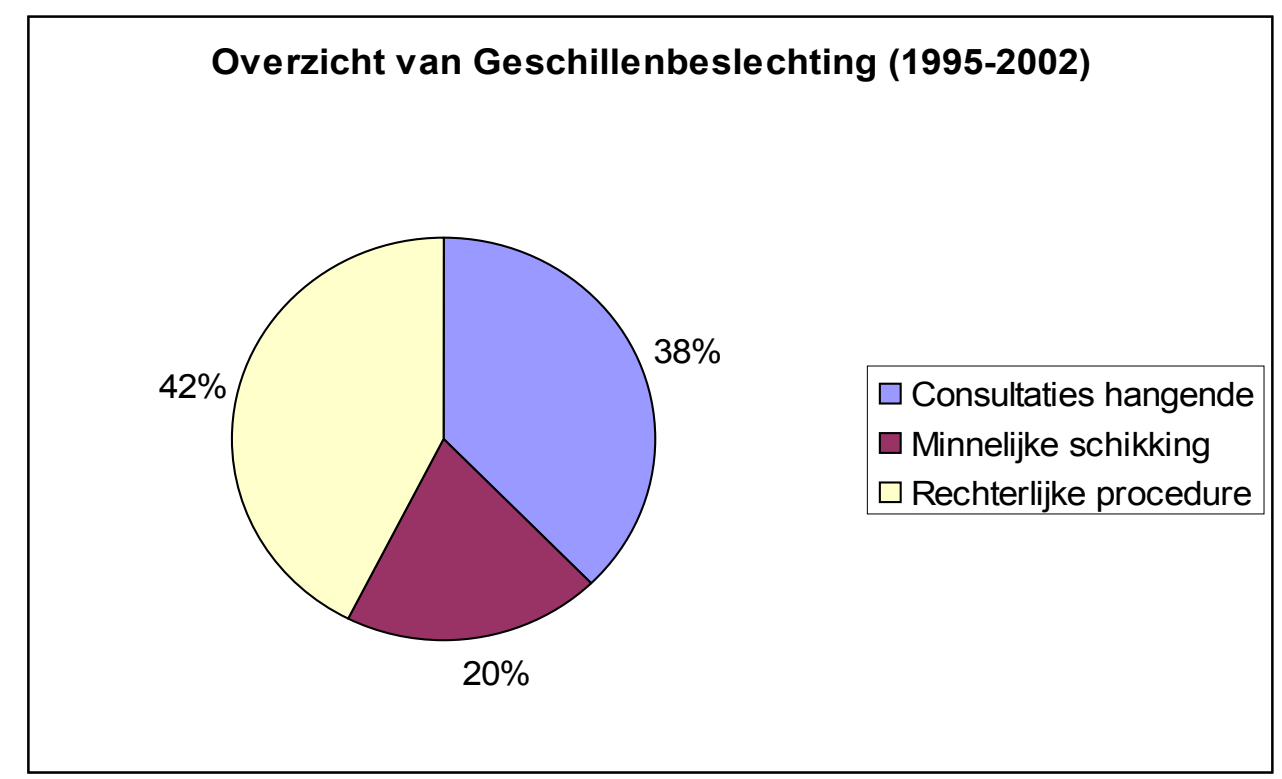

\subsection{Panelrapporten}

Tot op heden hebben panels 80 panelrapporten aangenomen. ${ }^{18}$ Tot en met 2000 is het aantal panelrapporten elk jaar gestegen. In 2001 is er echter een duidelijke terugval in het aantal panelrapporten te bespeuren. Deze terugval is het gevolg van de daling van het aantal aanhangig gemaakte geschillen in 1999.

17 Omdat geschillen soms gevoegd worden, komt aantal geschillen dat aan een panel werd voorgelegd niet overeen met het aantal gevormde panels. In deze cijfers werd ook geen rekening gehouden met de enkele geschillen die aan een panel werden voorgelegd maar waarin een minnelijke schikking werd getroffen tijdens de panelprocedure.

18 Zie http://www.worldtradelaw.net/dsc/database/wtopanels.asp, bezocht op 19 september 2002. Dit aantal omvat de artikel 21.5 panelrapporten maar niet de panelrapporten in geschillen waarin tijdens de panelprocedure een minnelijke schikking werd getroffen. 


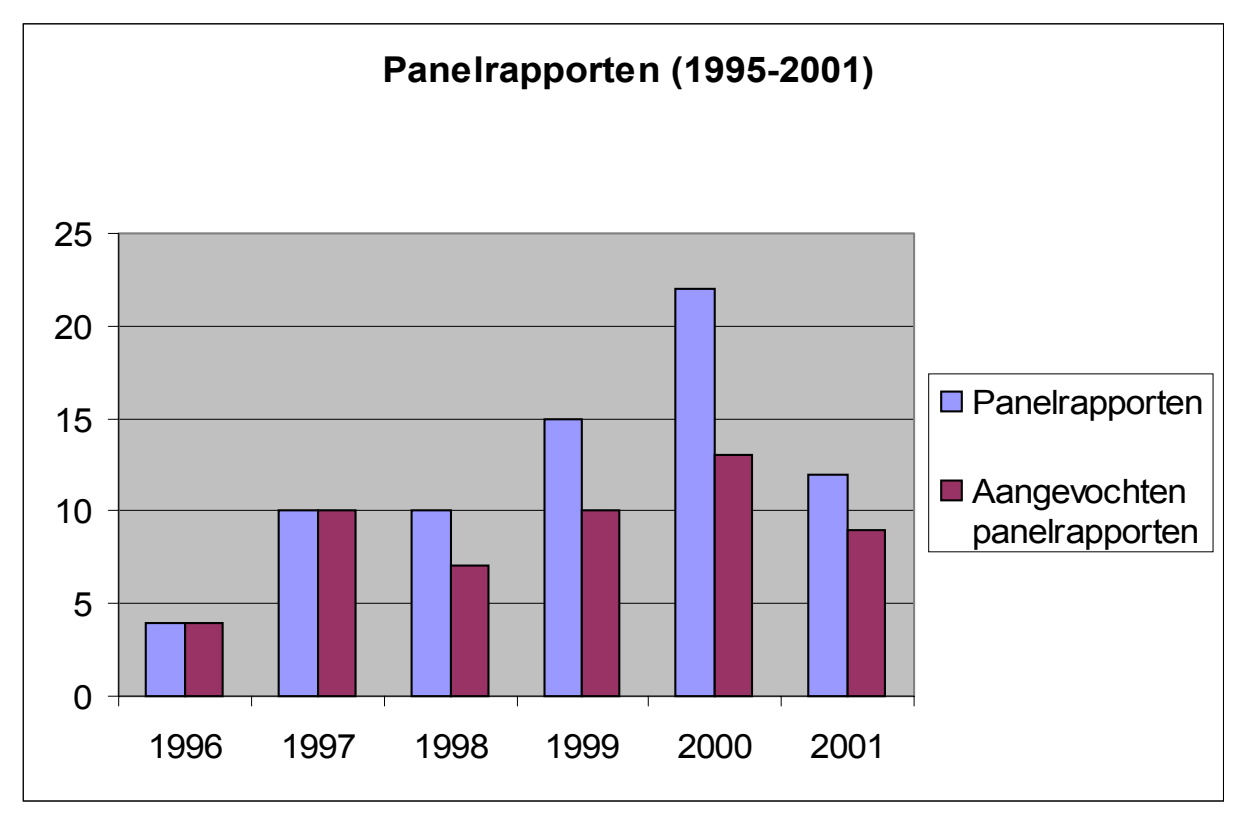

Tegen 57 panelrapporten, ofwel 75 procent van alle panelrapporten, zijn één of meerdere partijen in beroep gegaan bij de Beroepsinstantie. ${ }^{19}$ Aanvankelijk werd er tegen elk panelrapport beroep aangetekend. In 2000 daalde het aantal betwiste panelrapporten tot 60 procent maar in 2001 was dat aantal terug gestegen tot 75 procent. De voorlopige cijfers van 2002 bevestigen dat het percentage van panelrapporten waartegen partijen in beroep gaan hoog blijft. Dat is niet verwonderlijk want een partij die door het panel in het ongelijk wordt gesteld, heeft weinig te verliezen door beroep aan te tekenen.

De juridische kwaliteit van panelrapporten is in de loop van de jaren zeker verbeterd. Terwijl de panels onder het oude GATT systeem rapporten schreven die zoveel mogelijk voor klager en verweerder politiek aanvaardbaar waren, schrijven de panels onder het WTO systeem rapporten die de kritische, juridische beoordeling van de Beroepsinstantie kunnen doorstaan. Gelet op de moeilijke omstandigheden waaronder gewerkt moet worden, leveren de panels veelal goed werk. ${ }^{20}$

\subsection{Rapporten van de Beroepsinstantie}

Tot op heden heeft de Beroepsinstantie 48 rapporten aangenomen. ${ }^{21}$ Het aantal rapporten van de Beroepsinstantie is van 1996 tot 1999 snel gestegen van 2 tot 10 per jaar en is in 2000 en 2001 ongeveer op dat niveau gebleven. De voorlopige cijfers van 2002 geven een daling van het aantal rapporten aan maar die trend kan nog worden omgebogen. ${ }^{22}$

$19 \mathrm{Zie} \mathrm{http://www.worldtradelaw.net/dsc/database/appealcount.asp,} \mathrm{bezocht} \mathrm{op} 19$ september 2002.

20 Met betrekking tot de moeilijke omstandigheden waaronder panels moeten werken, zie infra.

$21 \mathrm{Zie} \mathrm{http://www.worldtradelaw.net/dsc/database/abreports.asp} \mathrm{(bezocht} \mathrm{op} 19$ september 2002). Dit aantal omvat ook artikel 21.5 rapporten van de Beroepsinstantie.

22 Er zijn momenteel 4 beroepsprocedures hangende. 


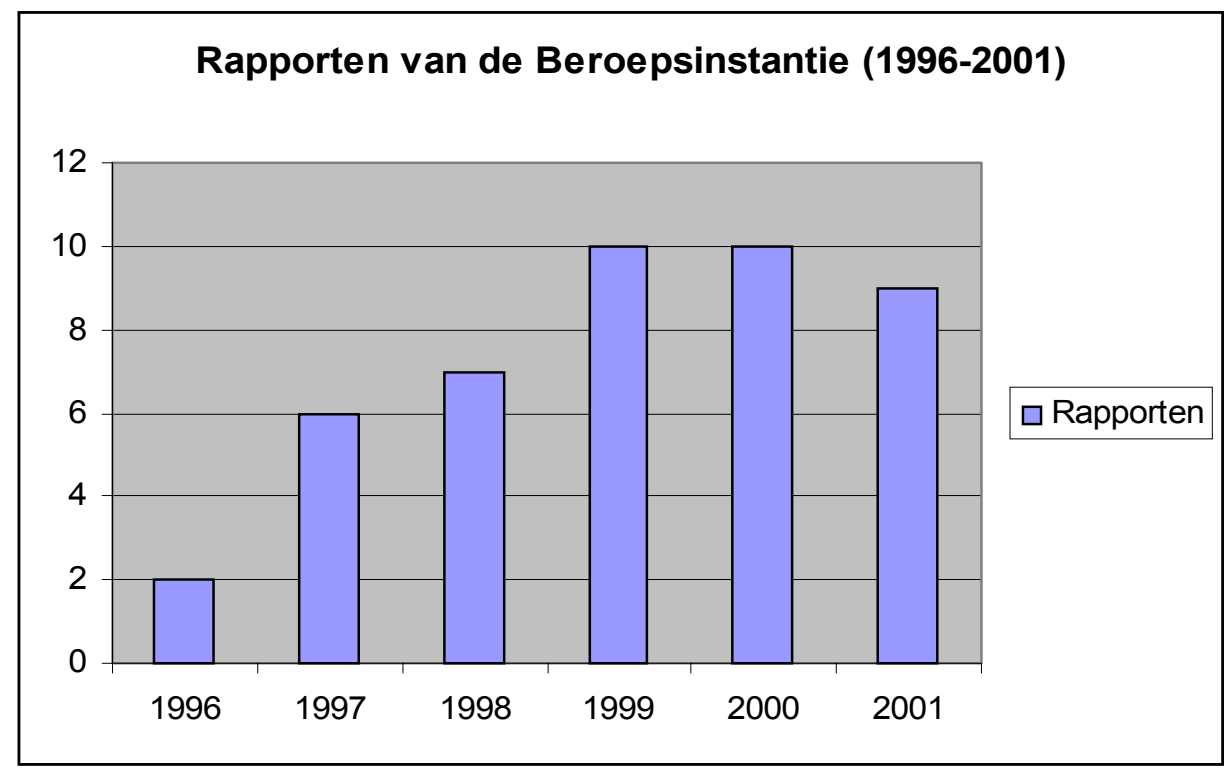

Ongeveer 20 procent van de panelrapporten waartegen beroep werd aangetekend, werd door de Beroepsinstantie volledig bevestigd terwijl ongeveer 75 procent van de panelrapporten door de Beroepsinstantie in min of meerdere mate werd gewijzigd. Slechts in twee van de 48 beroepsprocedures werd het betrokken panelrapport door de Beroepsinstantie vernietigd.

\section{Resultaat van beroepsprocedures (1996-2002)}

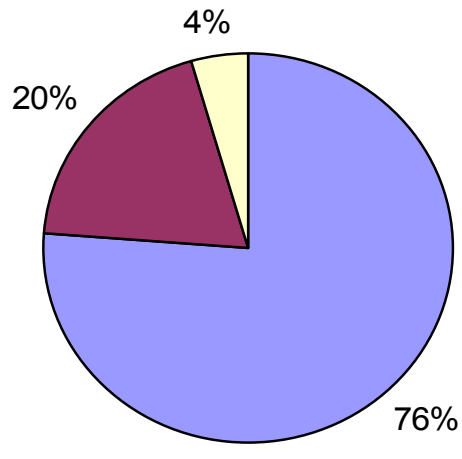

Gewijzigde panelrapporten

$\square$ Bevestigde panelrapporten

$\square$ Vernietigde panelrapporten

Volgens sommigen is de Beroepsinstantie vaak te kritisch en worden volstrekt redelijke juridische redeneringen van panels al te gemakkelijk opzij geschoven en vervangen door redeneringen van de Beroepsinstantie. Sommigen hebben zich ook gestoord aan het harde oordeel van de Beroepsinstantie over juridische redeneringen van panels en aan de "schoolmeesterachtige" toon van de rapporten van de Beroepsinstantie. Het is een feit dat zeker in de beginperiode enkele gerenommeerde panelleden zich terecht of ten onrechte door de Beroepsinstantie diep gekrenkt hebben gevoeld. 


\subsection{Duur van panel- en beroepsprocedures}

Zoals reeds vermeld zijn de panel- en beroepsprocedures gebonden aan strikte procestermijnen. Zo zou een panelprocedure niet langer dan negen maanden mogen duren. In de praktijk duurt een panelprocedure echter gemiddeld 12 maanden. ${ }^{23}$ Een artikel 21.5 panelprocedure die slechts drie maanden zou mogen duren, duurt in de praktijk gemiddeld vijf en een halve maand. ${ }^{24}$ De procedure voor de Beroepsinstantie mag niet langer dan 90 dagen duren. De Beroepsinstantie heeft in slechts vier van de 48 procedures deze termijn overschreden. Voor zowel panels als de Beroepsinstantie stelt zich echter de vraag of de procestermijnen met de huidige inzet en beschikbaarheid van personele middelen niet onredelijk kort zijn. Anderzijds mag men niet uit het oog verliezen dat hoe langer de procedures duren, hoe langer een inbreuk op het WTO recht blijft bestaan en dit is problematisch in een systeem dat niet voorziet in de vergoeding van schade geleden als gevolg van een inbreuk. ${ }^{25}$

\subsection{Naleving van de uitspraken}

Zoals hierboven besproken, beschikt het WTO geschillenbeslechtingssysteem over een uniek mechanisme om de naleving van panelrapporten en rapporten van de Beroepsinstantie te bewerkstelligen. Heeft dat mechanisme echter ook naar behoren gewerkt? In ongeveer 85 procent van de geschillen waarin panels en/of de Beroepsinstantie oordeelden dat een maatregel van een Lid onverenigbaar was met het WTO recht, hebben de betrokken Leden onmiddellijk of binnen de vastgestelde "redelijke termijn" de onrechtmatige maatregel ook ingetrokken of afdoende gewijzigd. In slechts 15 procent van de geschillen is dit niet gebeurd of was er betwisting tussen de partijen over de vraag of dit gebeurd is. Voorbeelden ${ }^{26}$ hiervan zijn de Bananen-zaak, de Hormonen-zaak, de Zalm-zaak ${ }^{27}$, de FSC-zaak, de Canadese Melkzaak $^{28}$ en de Regionale Vliegtuigen-zaak: In deze geschillen rezen er problemen met betrekking tot de naleving van de panelrapporten en/of de rapporten van de Beroepsinstantie. De oorspronkelijke klagers in die geschillen deden dan ook een beroep op de bijzondere procedures die het WTO systeem voorziet voor dit soort situaties. Tot dusver hebben panels 13 maal onderzocht of een Lid al dan niet maatregelen had genomen ter naleving van een uitspraak en onderzocht of de genomen maatregelen verenigbaar zijn met het WTO recht. In zes van deze geschillen heeft de Beroepsinstantie een beroep tegen het panelrapport over de naleving van de uitspraak behandeld. In 2000 en 2001 waren er telkens vier panelrapporten over de naleving van uitspraken. De voorlopige cijfers van 2002 duiden op een daling van het aantal van deze panelrapporten.

23 Zie http://www.worldtradelaw.net/dsc/database/paneltiming.asp.

$24 \mathrm{Zie}$ http://www.worldtradelaw.net/dsc/database/paneltiming1.asp.

25 De compensatie waarvan eerder en hierna sprake is vrijwillige compensatie voor "schade" geleden nadat de schending van het WTO recht is vastgesteld en nadat de redelijke termijn voor de tenuitvoerlegging van de uitspraak is verstreken.

26 Voor een volledige lijst, zie: http://www.worldtradelaw.net/dsc/database/art215reports1.asp.

27 Australia - Measures Affecting Importation of Salmon ("Zalm-zaak"), WT/DS18.

28 Canada-Measures Affecting the Importation of Milk and the Exportation of Dairy Products ("Canadese Melkzaak"), WT/DS103, WT/DS113. 


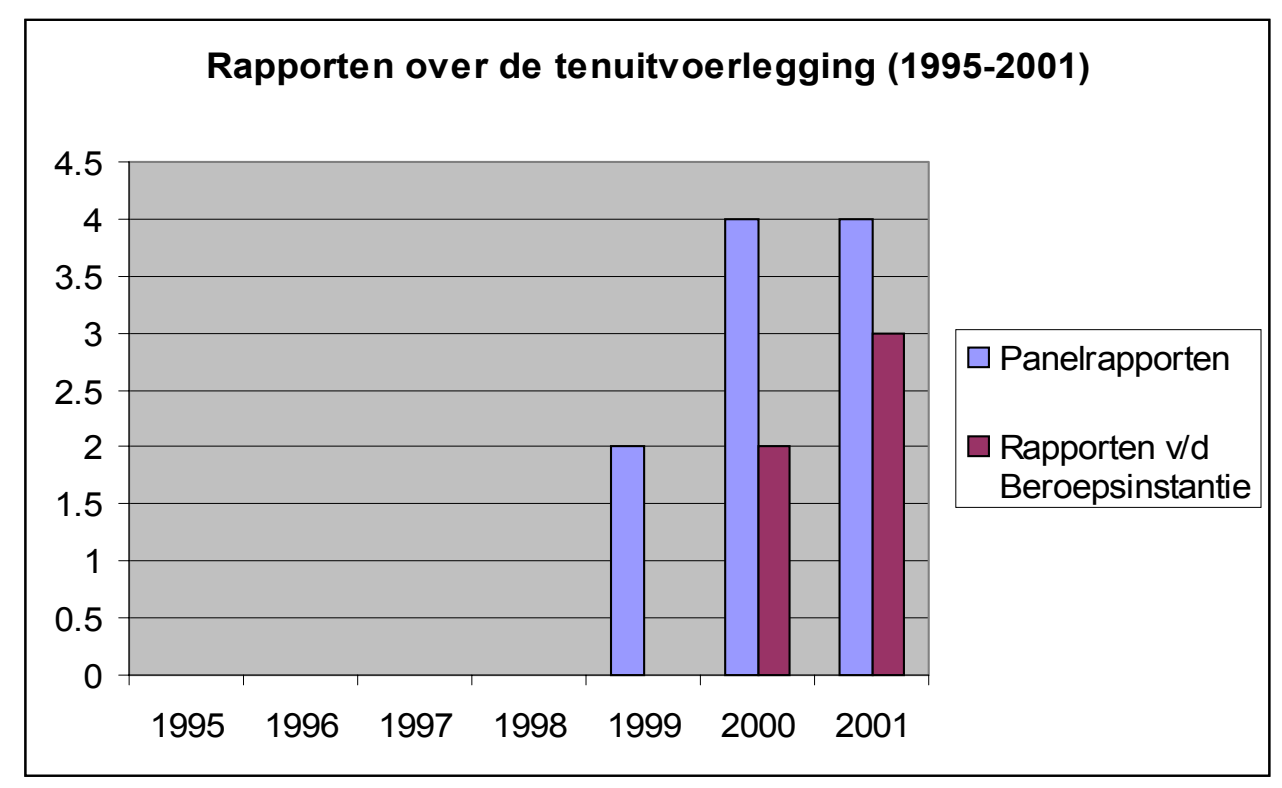

Toen er zich eind 1998 voor het eerst een probleem met de tenuitvoerlegging van een uitspraak voordeed in het kader van de Bananen-zaak bleek dat er een ernstige fout in het systeem zat. De termijn voor de procedure voor het vaststellen van de verenigbaarheid met het WTO recht van de uitvoeringsmaatregelen is onverenigbaar met de termijn voor het bekomen van een machtiging van het Orgaan voor Geschillenbeslechting om strafmaatregelen te nemen. De procedure voor het bekomen van een machtiging om strafmaatregelen te nemen voor het niet naleven van een uitspraak moet zijn afgerond op een ogenblik dat de procedure om vast te stellen of de uitspraak al dan niet is nageleefd nog lang niet is afgerond. Dit probleem heeft aanleiding gegeven tot een ernstig meningsverschil tussen de Verenigde Staten en de Europese Unie. De Verenigde Staten stond op het standpunt dat een Lid kon worden gemachtigd om strafmaatregelen te nemen voor de niet-naleving van een uitspraak ook al was er onenigheid tussen de partijen over de vraag of een uitspraak al dan niet was nageleefd. De Verenigde Staten eigende zich aldus het recht toe eenzijdig te beslissen of er naleving van een uitspraak was of niet. De Europese Unie was van oordeel dat een Lid enkel kon worden gemachtigd om sancties te nemen voor de niet-naleving van een uitspraak nadat er volgens de daarvoor voorziene multilaterale procedure was vastgesteld dat er geen correcte naleving van de uitspraak was geweest. Dit meningsverschil leidde in januari 1999 tot een institutionele crisis binnen de WTO. Deze crisis werd echter dankzij de bemiddeling van de toenmalige Directeur-generaal Renato Ruggiero opgelost met een pragmatisch, politiek akkoord. In latere geschillen hebben de Leden, met inbegrip van de Verenigde Staten, ad hoc akkoorden gesloten om eerst te laten vaststellen of een uitspraak correct is nageleefd alvorens het Orgaan voor Geschillenbeslechting eventueel een machtiging tot het nemen van strafmaatregelen te laten verlenen. Door deze ad hoc akkoorden is dit zogenoemde "sequencing" probleem niet langer acuut. Deze akkoorden herstellen echter niet de ernstige fout die in het Memorandum over Geschillenbeslechting zit en zijn strikt genomen contra legem.

Hoewel het mechanisme dat de naleving van uitspraken moet bewerkstelligen dus duidelijk nog niet optimaal is, zijn tijdens de periode van 1995 tot 2002 de meeste uitspraken zonder noemenswaardige problemen tijdig en correct ten uitvoer gelegd. De enkele rapporten die niet tijdig en correct zijn ten uitvoer zijn gelegd, zoals de rapporten in de Bananen-zaak, de 
Hormonen-zaak en de FSC-zaak, hebben echter veel aandacht gekregen en hebben de algemene perceptie over het functioneren van het systeem vervormd.

\subsection{Compensatie en strafmaatregelen}

In de periode van januari 1995 tot augustus 2002 hebben de partijen in geschillen waarin de verweerder de uitspraak niet tijdig en correct heeft ten uitvoer gelegd, slechts een enkele keer een akkoord over vrijwillige compensatie bereikt. Dit gebeurde bijvoorbeeld in de Japanse Alcohol-zaak ${ }^{29}$, waarin Japan de Europese Unie, de Verenigde Staten en Canada heeft gecompenseerd tijdens de periode van niet-naleving van de uitspraak in die zaak. In het algemeen gesproken, heeft vrijwillige compensatie echter niet goed gewerkt als middel om de naleving van uitspraken te bewerkstelligen.

Tot op heden heeft het Orgaan voor Geschillenbeslechting vijf keer een Lid gemachtigd om strafmaatregelen wegens de niet-naleving van uitspraken te nemen. Dit gebeurde tweemaal in de Bananen-zaak (strafmaatregelen tegen de Europese Unie op verzoek van de Verenigde Staten en op verzoek van Ecuador); tweemaal in de Hormonen-zaak (strafmaatregelen tegen de Europese Unie op verzoek van de Verenigde Staten en op verzoek van Canada); en éénmaal in de Regionale Vliegtuigen-zaak (strafmaatregelen tegen Brazilië op verzoek van Canada). Voorafgaand aan het verlenen van de machtiging werd in elk van deze gevallen de gepaste hoogte van de strafmaatregelen bepaald door het panel volgens de arbitrage procedure voorzien in artikel 22 van het Memorandum over Geschillenbeslechting. De zwaarste strafmaatregel waarvoor tot nu toe machtiging werd gegeven was de strafmaatregel ten bedrage van \$201.6 miljoen per jaar die Ecuador tegen de Europese Unie mocht nemen wegens de niet-naleving van de Bananen-rapporten. Die strafmaatregel werd echter nooit toegepast omdat Ecuador tot de conclusie kwam dat het toepassen van die maatregel de Ecuadoriaanse economie meer zou schaden dan de economie van de Europese Unie. Ook de strafmaatregel die Canada mocht toepassen ten aanzien van Brazilië in de Vliegtuigen-zaak werd nooit toegepast. De strafmaatregel toegepast door de Verenigde Staten ten aanzien van de Europese Unie in het kader van de Bananen-zaak werd vorig jaar opgeheven nadat de Europese Unie correcte uitvoering aan de Bananen-rapporten had gegeven. Die strafmaatregel ten bedrage van \$ 191.4 miljoen per jaar heeft er ongetwijfeld toe bijgedragen dat de Europese Unie uiteindelijk (te weten 30 maanden na het verstrijken van de redelijke termijn voor de tenuitvoerlegging) toch haar invoerregime voor bananen in overeenstemming met het WTO recht heeft gebracht. De enige strafmaatregelen die op dit ogenblik worden toegepast zijn de strafmaatregelen tegen de Europese Unie in de Hormonen-zaak. Er is wel een verzoek van de Europese Unie om een strafmaatregel te mogen nemen tegen de Verenigde Staten in de FSC-zaak momenteel in behandeling bij het Orgaan voor Geschillenbeslechting. Zoals eerder vermeld heeft het panel in deze zaak op 24 augustus 2002 de gepaste hoogte van de strafmaatregel bepaald op $\$ 4$ miljard per jaar.

De Bananen-zaak heeft duidelijk gemaakt dat het toepassen van strafmaatregelen om een Lid te dwingen tot naleving van een uitspraak voor ontwikkelingslanden vaak geen realistische optie is. Zoals reeds uiteengezet, bestaat een strafmaatregel uit het schorsen van concessies of andere verplichtingen. De invoerrechten op bepaalde producten van het betrokken Lid worden bijvoorbeeld verhoogd tot 100 procent ad valorem. Een dergelijke verhoging treft echter niet alleen het betrokken Lid maar ook het Lid dat de strafmaatregel oplegt omdat de invoer van

${ }_{29}$ Japan-Taxes on Alcoholic Beverages ("Japanse Alcohol-zaak"), WT/DS8, WT/DS10, WT/DS11. 
bepaalde producten duurder wordt. Ontwikkelingslanden kunnen zich dat vaak niet veroorloven. Meer in het algemeen moet worden opgemerkt dat strafmaatregelen voor alle betrokkenen bij het geschil handelsvernietigend zijn terwijl het toch juist de bedoeling is van het geschillenbeslechtingssysteem om de handel te bevorderen. Tenslotte worden strafmaatregelen ook als "onrechtvaardig" ervaren omdat de betrokken producten vaak geproduceerd en verhandeld worden door ondernemingen die niets te maken hebben met de maatregel die het WTO recht schendt. Zo zijn de strafmaatregelen in de Hormonen-zaak gericht tegen o.a. Franse kaas en Italiaanse lederwaren.

\subsection{Bijdrage tot de ontwikkeling van het WTO recht}

De rapporten van panels maar vooral de rapporten van de Beroepsinstantie hebben tijdens de periode van 1995 tot 2002 in belangrijke mate bijgedragen tot de verduidelijking en verdere ontwikkeling van het WTO recht. Dit is o.a. het geval geweest met betrekking tot de toepassing van artikel XX van de GATT 1994, een bepaling die een belangrijke rol speelt in het "verzoenen" van vrije handel met maatschappelijke waarden zoals het milieu en volksgezondheid (zie de Benzine-zaak, de Garnalen-zaak en de Asbestos-zaak). Hoewel dit niet altijd onmiddellijk is begrepen door niet-gouvernementele organisaties actief op deze gebieden, laat de rechtspraak van de Beroepsinstantie ruime bevoegdheid aan WTO Leden om handelsbeperkende maatregelen ter bescherming van het milieu of de volksgezondheid te nemen. De rechtspraak van panels en de Beroepsinstantie hebben ook bijgedragen tot de verduidelijking van artikel III van de GATT 1994 betreffende niet-discriminatie tussen ingevoerde en nationale producten (zie de Asbestos-zaak en de Alcohol-zaken); de bepalingen van het SPS Overeenkomst (zie de Hormonen-zaak, de Zalm-zaak en de Landbouwproductenzaak); de regels betreffende vrijwaringsmaatregelen, de regels betreffende dumping en, tenslotte, de regels betreffende subsidies en tegenmaatmaategelen.

Panels en vooral de Beroepsinstantie hebben ook de regels en procedures van het geschillenbeslechtingssysteem verduidelijkt (en aangevuld). Ik denk hier o.a. aan de regels met betrekking tot de bewijslast, regels met betrekking tot de functie en de bevoegdheid van panels (o.a. "standard of review"), en de regels met betrekking tot de vertegenwoordiging van partijen door advocaten.

De rechtspraak van de Beroepsinstantie met betrekking tot "amicus curiae briefs" en de uitspraak van het Panel in de Leder-zaak met betrekking tot de terugbetaling van onrechtmatige exportsubsidies is door een grote meerderheid van de Leden zwaar bekritiseerd. De rest van de rechtspraak is echter algemeen aanvaard en doorgaans enkel bekritiseerd door de verliezende partij. Vooral de Verenigde Staten heeft zich zo tijdens de laatste twee jaar erg negatief uitgelaten over rechtspraak van de Beroepsinstantie met betrekking tot de "standard of review" in geschillen over vrijwaringsmaatregelen. Ook de rechtspraak van de Beroepsinstantie met betrekking tot de interpretatie van nationaal recht door panels en de Beroepsinstantie is door de Verenigde Staten bekritiseerd. In het algemeen gesproken, is de rechtspraak van panels en de Beroepsinstantie, met haar verduidelijkingen en voorzichtige "aanvullingen" van het WTO recht, door de Leden aanvaard. Dit is ongetwijfeld in belangrijke mate te danken aan het feit dat de Beroepsinstantie en panels in de regel kiezen voor een op de tekst van de verdragsbepalingen gebaseerde interpretatie. De teleologische interpretatiemethode, gebruikelijk bij het Europees Hof van Justitie in Luxemburg, wordt niet gevolgd. De rapporten van panels en de Beroepsinstantie hebben - zoals artikel 3.2 van het 
Memorandum over Geschillenbeslechting dat vereist - bijgedragen tot meer (rechts)zekerheid en voorspelbaarheid in de handelsrelaties tussen staten.

\subsection{Samenvattend}

Uit de voorgaande analyse moge blijken dat in het algemeen gesproken het WTO geschillenbeslechtingssysteem tot dusver daadkrachtig en effectief heeft gefunctioneerd. Het WTO geschillenbeslechtingssysteem is het meest gebruikte multilateraal systeem voor het beslechten van internationale geschillen. Het systeem is veelvuldig gebruikt door zowel geïndustrialiseerde landen als ontwikkelingslanden. De aanhangig gemaakte geschillen betroffen ook politiek en maatschappelijk erg gevoelige onderwerpen zoals de bescherming van het milieu en de volksgezondheid. In die geschillen waarin geen oplossing kon worden bereikt door onderhandelingen, hebben panels en de Beroepsinstantie binnen relatief korte tot zeer korte termijnen uitspraak gedaan. De Beroepsinstantie heeft in vele gevallen de argumentatie van het panel gewijzigd maar heeft tot nu toe slechts tweemaal een panelrapport geheel verworpen. De meeste panelrapporten en rapporten van de Beroepsinstantie zijn tijdig en correct ten uitvoer gelegd. In alvast één geval waarin dat niet zo was, de Bananen-zaak, heeft de toegepaste strafmaatregel er ongetwijfeld toe bijgedragen dat de Europese Unie uiteindelijk toch zijn wetgeving WTO-conform heeft gemaakt. Hoewel het WTO geschillenbeslechtingssysteem dus goed heeft gewerkt, heeft acht jaar ervaring met dit systeem ons echter ook geleerd dat het op een flink aantal punten nog kan verbeterd worden.

\section{Een beter WTO geschillenbeslechtingssysteem?}

\subsection{De Doha Ontwikkelingsronde}

De vraag of en hoe het WTO geschillenbeslechtingssysteem nog verder kan worden verbeterd is een zeer actuele vraag. De hervorming van het geschillenbeslechtingssysteem staat immers op de agenda van de Doha Ontwikkelingsronde, een nieuwe onderhandelingsronde over de regels van het multilateraal handelssysteem die in januari van dit jaar van start is gegaan en in januari 2005 zou moeten worden afgerond. De onderhandelingen over eventuele wijzigingen van het geschillenbeslechtingssysteem zouden volgens de Slotakte van de Ministeriële Conferentie van Doha zelfs reeds in mei 2003 moeten worden afgerond. De onderhandelingen over het geschillenbeslechtingssysteem worden van de andere onderhandelingen gescheiden gehouden omdat men van oordeel is dat de hervorming van het geschillenbeslechtingssysteem niet het voorwerp mag zijn van klassieke "voor wat, hoort wat" onderhandelingen. Een beter geschillenbeslechtingssysteem is immers in het belang van alle Leden. Of echter mei 2003 een realistische einddatum voor de onderhandelingen over het geschillenbeslechtingssysteem is, mag worden betwijfeld. Wel moet worden opgemerkt dat de huidige onderhandelingen kunnen voortbouwen op formele en informele onderhandelingen die van 1998 tot 2001 hebben plaatsgevonden. 


\subsection{Voorstellen tot hervorming van het geschillenbeslechtingssysteem}

De onderhandelingen over het geschillenbeslechtingssysteem zijn momenteel volop aan de gang. De Europese Unie ${ }^{30}$, Thailand ${ }^{31}$, de Filippijnen en Thailand ${ }^{32}$, Ecuador ${ }^{33}$, Australieie ${ }^{34}$, Korea $^{35}$ en de Verenigde Staten $^{36}$ hebben formele voorstellen tot hervorming van het geschillenbeslechtingssysteem gedaan. Verder circuleert er een werkdocument met hervormingsvoorstellen van een groep van 15 geïndustrialiseerde landen en Latijnsamerikaanse ontwikkelingslanden. ${ }^{37}$ Men kan de hervormingsvoorstellen onderverdelen in twee grote groepen: voorstellen tot wijziging van de procedures voor geschillenbeslechting en voorstellen tot wijziging van de organen van geschillenbeslechting. Met betrekking tot de procedures voor geschillenbeslechting, zijn er voorstellen die de duur van de procedures betreffen, voorstellen met betrekking tot de openbaarheid van en de toegang tot de procedures, voorstellen met betrekking tot de procedure voor het vaststellen van de nietnaleving van uitspraken, en voorstellen met betrekking tot compensatie en strafmaatregelen bij niet-naleving van uitspraken. Met betrekking tot de organen voor geschillenbeslechting, zijn er voorstellen met betrekking tot de samenstelling en werking van panels en de Beroepsinstantie. Het is niet mijn bedoeling om hier alle voorstellen te bespreken. Ik wil mij beperken tot een bespreking van slechts twee onderwerpen waaromtrent opmerkelijke en controversiële hervormingsvoorstellen zijn gedaan. Deze onderwerpen zijn de samenstelling van panels en de maatregelen om de naleving van uitspraken te bewerkstelligen.

\subsection{Problemen en voorstellen die buiten beschouwing blijven}

Ik neem aan dat weinigen onder $\mathrm{U}$ zullen betreuren dat ik niet inga op het zogenoemde "sequencing" probleem, d.i. het probleem van de verhouding tussen artikel 21.5 en artikel 22 van het Memorandum over Geschillenbeslechting. Dit probleem is het gevolg van een slordigheid bij het schrijven van het Memorandum maar heeft, zoals eerder vermeld, in het kader van de Bananen-zaak begin 1999 geleid tot een ernstige institutionele crisis. Sinds die donkere dagen heeft er zich echter een praktijk tussen WTO Leden ontwikkeld die het probleem «oplost». Ik heb goede hoop dat het Memorandum zal worden gewijzigd in de zin van die praktijk. Het kan immers niet anders dan dat strafmaatregelen wegens niet-naleving

30 "Contribution of the European Communities and its Member States to the Improvement of the WTO Dispute Settlement Understanding, TN/DS/W/1, dated 13 March 2002; en "The European Communities' Replies to India's Questions", TN/DS/W/7, dated 24 May 2002. Zie ook: The Benefits of Moving From Ad Hoc to More Permanent Panellists, Non-Paper, DG Trade/D/3/PG D(2002), dated 10 July 2002.

31 Communication from Thailand, Proposal to Review Article 17.1 of the Understanding on Rules and Procedures Governing the Settlement of Disputes, TN/DS/W/2, dated 20 March 2002.

32 Communication from the Philippines and Thailand, Proposal to Review Article 22.7 of the Understanding on Rules and Procedures Governing the Settlement of Disputes, TN/DS/W/3, dated 21 March 2002.

33 Contribution of Ecuador to the Improvement of the Dispute Settlement Understanding of the WTO, TN/DS/W/9, dated 8 July 2002.

34 Negotiations on Improvements and Clarifications of the Dispute Settlement Understanding, Communication from Australia, TN/DS/W/8, dated 8 July 2002.

35 Contribution of the Republic of Korea to the Improvement of the Dispute Settlement Understanding of the WTO, TN/DS/W/11, dated 11 July 2002.

36 Contribution of the United States to the Improvement of the Dispute Settlement Understanding of the WTO Related to Transparency, TN/DS/W/13, dated 22 August 2002.

37 Deze groep bestaat uit Bolivië, Canada, Chile, Colombia, Costa Rica, Ecuador, Guatemala, Japan, Korea, Nieuw Zeeland, Noorwegen, Peru, Zwitserland, Uruguay en Venezuela. De concept paper van deze groep, Remedying the Dispute Settlement Understanding's Articles 21.5/22 “Sequencing” Issue, JOB(02)/45 is gedateerd 27 mei 2002. 
van een uitspraak pas kunnen worden genomen nadat het geschillenbeslechtingssysteem heeft vastgesteld dat er inderdaad sprake is van niet-naleving.

Tevens zal ik niet ingaan op de problemen van de "amicus curiae briefs" en het besloten karakter van het gehele procesverloop. Laat mij enkel dit zeggen. Ik sta volledig achter de rechtspraak van de Beroepsinstantie over "amicus curiae briefs" en heb nooit goed begrepen waarom de overgrote meerderheid van de WTO Leden zich zo passioneel tegen deze rechtspraak heeft gekeerd. Voorstellen van de Europese Unie en de Verenigde Staten om deze rechtspraak te bekrachtigen maken dan ook mijns inziens weinig kans op slagen. Met betrekking tot de openbaarheid van de procedures, of beter, het absolute gebrek aan openbaarheid, ben ik van oordeel dat er geen enkele rechtvaardiging is voor de beslotenheid die WTO geschillenbeslechting nu kenmerkt. Zoals hierboven opgemerkt, is deze beslotenheid een erfenis uit de tijd dat het systeem voor het beslechten van handelsgeschillen nog een diplomatiek geschillenbeslechtingssysteem was. Die tijd is voorbij. Indien het WTO geschillenbeslechtingssysteem aan legitimiteit en geloofwaardigheid wil winnen, is de tijd gekomen om in beginsel hoorzittingen niet langer achter gesloten deuren te houden en processtukken openbaar te maken. Ik hoop dat de voorzichtige voorstellen van de Europese Unie in dit verband door de ontwikkelingslanden niet onmiddellijk van de onderhandelingstafel zullen worden geveegd. Op deze problemen ga ik echter vandaag niet verder in. Zoals gezegd wil ik het met $U$ verder vooral hebben over de samenstelling van panels en over de maatregelen om de naleving van uitspraken te bewerkstelligen.

\section{Samenstelling van panels}

Zoals reeds vermeld zijn panels momenteel tijdelijke organen die worden gevormd voor het beslechten van een welbepaald geschil en zijn samengesteld uit ad hoc panelleden. Deze "gelegenheidspanelleden" zijn vaak diplomaten of ambtenaren afkomstig uit landen die niet direct bij het geschil betrokken zijn. Ad hoc panelleden doen het panelwerk naast vaak zware beroepstaken.

\subsection{Voorstel van de Europese Unie}

De Europese Unie wil nu de werking van panels "professionaliseren" en stelt voor een beperkte groep van permanente panelleden te benoemen. ${ }^{38}$ Deze "beroepspanelleden" zouden worden benoemd door het Orgaan voor Geschillenbeslechting op voorstel van de WTO Leden. Om hun onafhankelijkheid en onpartijdigheid te verzekeren, zouden de panelleden benoemd worden voor een niet-hernieuwbare ambtstermijn van bijvoorbeeld zes jaar en mogen de panelleden tijdens die termijn in principe geen enkele binding hebben met de overheid van een WTO Lid. De permanente panelleden zouden om de beurt en telkens met drie in een panel zetelen. De nationaliteit van de panelleden zou bij de samenstelling van een panel niet relevant zijn. ${ }^{39}$ Het benoemen van permanente panelleden zou een belangrijke

38 Zie: "Contribution of the European Communities and its Member States to the Improvement of the WTO Dispute Settlement Understanding”, TN/DS/W/1, dated 13 March 2002, pp. 2-4 and 9-10, "The European Communities' Replies to India's Questions", TN/DS/W/7, dated 24 May 2002, pp. 2-5, en “The Benefits of Moving From Ad Hoc to More Permanent Panellists", Non-Paper, DG Trade/D/3/PG D(2002), dated 10 July 2002, pp. 1-9.

39 De Europese Unie stelt echter wel voor om artikel 8.10 van het Memorandum over Geschillenbeslechting onveranderd te behouden. Krachtens dit artikel hebben ontwikkelingslanden die in een geschil betrokken zijn, recht op tenminste één panellid van een ontwikkelingsland. 
verdere stap zijn in het proces van de "verrechterlijking" van het WTO geschillenbeslechtingssysteem.

De Europese Unie rechtvaardigt haar voortstel door te wijzen op de groeiende kloof tussen de nood aan panelleden en de beschikbaarheid van voldoende gekwalificeerde ad hoc panelleden. De Europese Unie is van oordeel dat het werk van panelleden tijdens de laatste jaren zowel in omvang als in complexiteit sterk is toegenomen, en - zo mag men tussen de lijnen lezen - teveel en te moeilijk is geworden voor "gelegenheidspanelleden". De overstap naar "beroepspanelleden" zal, volgens de Europese Unie, leiden tot snellere procedures en kwalitatief betere panelrapporten. Bovendien meent de Europese Unie dat de onafhankelijkheid en de onpartijdigheid van "beroepspanelleden" beter kan worden gewaarborgd en dat dit de legitimiteit en de geloofwaardigheid van het geschillenbeslechtingssysteem zou versterken. Tenslotte argumenteert de Europese Unie dat de overstap naar "beroepspanelleden" zal leiden tot een betere vertegenwoordiging in panels van onderdanen van ontwikkelingslanden dan nu het geval is.

\subsection{Reacties op de verdere "verrechterlijking"}

Tot dusver heeft geen enkel ander Lid van de WTO zich openlijk achter dit radicale voorstel van de Europese Unie geschaard. Integendeel, een aantal Leden hebben zich over dit voorstel kritisch en wantrouwig uitgelaten. ${ }^{40}$ Een aantal Leden is ongetwijfeld bezorgd dat wanneer diplomaten en ambtenaren "in actieve dienst" niet langer meer in panels zouden zetelen, de Leden van de WTO nog minder "controle" over het geschillenbeslechtingssysteem zullen hebben dan nu reeds het geval is. Meer in het algemeen moet worden opgemerkt dat niet alle Leden erg gebrand zijn op een verdere "verrechterlijking" van het systeem. Sommigen dromen luidop van een terugkeer naar een meer diplomatiek geschillenbeslechtingssysteem hoewel het mij niet duidelijk is - zeker in het geval van ontwikkelingslanden - hoe een dergelijk systeem hun belangen beter zou dienen. In de discussies over het voorstel van de Europese Unie hoort men regelmatig dat wanneer doorgewinterde diplomaten en ambtenaren met jarenlange ervaring op het gebied van internationale handel niet langer als panelleden zouden kunnen dienen, dit een verarming voor het geschillenbeslechtingssysteem zou betekenen. Het relatieve succes van het oude GATT geschillenbeslechtingssysteem heeft ongetwijfeld veel te danken aan het pragmatisme en de politieke realiteitszin van de diplomaten en ambtenaren in actieve dienst die als panellid zetelden. De realiteit van vandaag is echter dat die doorgewinterde diplomaten of ambtenaren nu vaak niet beschikbaar zijn om als panellid te zetelen of gewraakt worden door één of beide partijen bij het geschil.

Ik ben een grote voorstander van het voorstel van de Europese Unie om een kleine groep van permanente panelleden te benoemen. Ik deel in grote mate de analyse die de Europese Unie maakt van de voordelen van de voorgestelde verandering: snellere procedures, kwalitatief betere panelrapporten, meer onafhankelijkheid en onpartijdigheid, en een evenwichtigere "vertegenwoordiging" van alle WTO Leden in panels. Dit voorstel verdient met overtuiging verdedigd te worden, ook al kan het nog verder worden uitgediept en aangescherpt.

40 Zie bijv.: "India's Questions to the European Communities and its Member States on their Proposal Relating to Improvements of the DSU", TN/DS/W/5, dated 30 April 2002, p. 1-4. 


\subsection{Aantal en statuut van permanente panelleden}

Ten aanzien van het aantal permanente panelleden en hun voltijds of deeltijds statuut neemt de Europese Unie momenteel een flexibel standpunt in. In maart 2002 was de Europese Unie nog duidelijk een aantal van 15 tot 24 panelleden met een voltijds statuut. $\mathrm{Nu}$ lijkt de Europese Unie eventueel ook een deeltijds statuut voor permanente panelleden willen te aanvaarden. De Europese Unie heeft ook berekend dat wanneer men zou kiezen voor voltijdse panelleden men met het huidige aantal geschillen beduidend minder dan 24 permanente panelleden zou nodig hebben. Uit de gemaakte berekeningen mag worden afgeleid dat 15 voltijdse panelleden zouden volstaan. Ik denk dat het zelfs met minder kan. Een deeltijds statuut voor permanente panelleden is echter geen goed idee en de Europese Unie zou op dit punt beter aan haar oorspronkelijke voorstel vasthouden. Deeltijdse panelleden zijn per definitie minder beschikbaar voor panelwerk en het gevaar van belangenconflicten is veel groter dan bij voltijdse panelleden. Dat deze problemen niet onoverkoombaar zijn, is aangetoond door de leden van de Beroepsinstantie, die allen - in theorie althans - een deeltijds statuut hebben. Dit deeltijds statuut wordt echter door een aantal WTO Leden, waaronder de Europese Unie, alsook door de leden van de Beroepsinstantie zelf als negatief voor hun optimaal functioneren ervaren. Sommige Leden geven misschien de voorkeur aan deeltijdse panelleden omdat zij vrezen dat hun best gekwalificeerde experts, om financiële of carrière redenen, niet geïnteresseerd zijn in een voltijdse betrekking als panellid. Gevreesd wordt dat bij een overstap naar voltijdse "beroepspanelleden" de groep van potentiële panelleden zal verkleinen. Naarmate echter het prestige verbonden aan een panellidmaatschap toeneemt en de WTO er voor zorgt dat de financiële en andere offers die van een permanent panellid worden gevergd niet onredelijk groot zijn, ben ik ervan overtuigd dat voldoende gekwalificeerde personen zich tot deze dienst aan de internationale gemeenschap zullen voelen geroepen.

\subsection{Kwalificaties van permanente panelleden}

Gelet op de belangrijke en moeilijke taak die panelleden moeten vervullen, betwist niemand dat permanente panelleden zeer bekwame en inhoudsdeskundige personen op het gebied van internationale handel moeten zijn. Volgens de Europese Unie moeten permanente panelleden echter niet noodzakelijk juristen zijn. De Europese Unie pleit ervoor dat - zoals nu het geval is - naast juristen ook experts in handelsbeleid en internationale economie deel zouden blijven uitmaken van panels. In mijn opvatting is het op zich niet zo belangrijk of panelleden al dan niet juristen zijn. Veel belangrijker is of panelleden de hun opgedragen taak naar behoren kunnen vervullen. Krachtens artikel 11 van het Memorandum over Geschillenbeslechting is het de taak van panelleden om de feiten in een geschil op objectieve wijze vast te stellen en dan te beoordelen of die feiten een inbreuk op het WTO recht vormen. Als de professionele kwalificaties van niet-juristen hen toelaten om deze taak naar behoren te vervullen, dan ben ik het met de Europese Unie eens dat ook niet-juristen hun plaats in panels hebben. Ik merk in dit verband op dat in de Beroepsinstantie steeds personen hebben gezeteld die geen jurist zijn of enkel kortstondig als jurist actief zijn geweest.

\subsection{Onafhankelijkheid en onpartijdigheid}

De onafhankelijkheid en onpartijdigheid van de rechter is in een rechterlijk geschillenbeslechtingssysteem van groot belang. Net als de leden van de Beroepsinstantie, 
zouden ook de permanente panelleden daarom tijdens hun mandaat als panellid geen banden met de overheid van een WTO Lid mogen hebben. Verder zouden de reeds bestaande Gedragsregels voor Geschillenbeslechting, en in het bijzonder de regels ter vermijding van reële of potentiële belangenconflicten, op permanente panelleden strikt moeten worden toegepast. Naar mijn mening kunnen ambtenaren en diplomaten van een Lid permanent panellid worden maar dan enkel op voorwaarde dat hun overheid voor de duur van hun mandaat met hen alle banden daadwerkelijk verbreekt. Het is waarschijnlijk verstandig teneinde alle vrees voor belangenconflicten weg te nemen dat een panellid met deze gouvernementele achtergrond niet zetelt in een panel dat kennisneemt van een geschil waarbij de overheid van dat panellid partij is.

\subsection{Specialisatie}

Het is duidelijk dat wanneer men kiest voor een beperkt aantal permanente panelleden die om de beurt en per drie in panels zetelen, men niet kan nastreven dat er in het panel dat kennisneemt van een geschil steeds panelleden zetelen die gespecialiseerd zijn op de deelgebieden van het WTO recht die in het geschil relevant zijn. In theorie kan dat met ad hoc panelleden wel. Die kunnen immers gekozen worden omwille van hun expertise op de relevante deelgebieden. In de praktijk lukt dat echter vaak niet en worden personen met weinig of geen specialistische kennis van de relevante deelgebieden gekozen of benoemd tot ad hoc panellid. In tegenstelling tot de huidige ad hoc panelleden, mag van permanente panelleden echter verwacht worden dat zij voldoende kennis hebben van alle deelgebieden van het WTO recht om geschillen met betrekking tot alle deelgebieden te beslechten. Indien een panel specifieke juridische of andere expertise nodig heeft, kan het steeds op grond van artikel 13 van het Memorandum over Geschillenbeslechting een beroep doen op externe deskundigen.

\subsection{Duur van panelprocedures}

De overstap naar permanente panelleden zal ook de gemiddelde duur van panelprocedures inkorten. Dit zal in de eerste plaats het gevolg zijn van het feit dat onmiddellijk na de vorming van een panel, dat panel zal kunnen worden samengesteld. Zo wordt zeker een maand gewonnen die nu besteed wordt aan onderhandelingen tussen de partijen over de samenstelling van het panel (minimum 20 dagen) en de beraadslaging van de Directeurgeneraal wanneer deze op verzoek van de klager het panel samen stelt (maximum 10 dagen). Panelprocedures zullen echter ook korter worden als gevolg van het feit dat de panelleden bestendig en voltijds beschikbaar zullen zijn voor panelwerk. Momenteel is het vaak moeilijk - en een oorzaak van vertraging - om datums voor panelbijeenkomsten en beraadslagingen te vinden die elk van de drie, druk bezette en over de wereld verspreide ad hoc panelleden schikken. De overstap naar "beroepspanelleden" zal het mogelijk maken om de procestermijnen van 6 en 9 maanden die in het Memorandum over Geschillenbeslechting zijn voorzien te respecteren. Zoals eerder gesteld, is dit in de meeste geschillen nu niet mogelijk.

Een overstap naar "beroepspanelleden" maakt het ook gemakkelijker om ervoor te zorgen dat de oorspronkelijke panelleden in een geschil beschikbaar zijn wanneer dient te worden onderzocht of de verwerende partij al dan niet de uitspraak correct ten uitvoer heeft gelegd of wanneer de hoogte van de strafmaatregelen moet worden bepaald. Het spreekt voor zich dat 
dit sneller en met meer kennis van zaken kan gebeuren door de oorspronkelijke panelleden. Zolang panelleden echter ad hoc zijn, zal het moeilijk blijven om dit te garanderen.

\subsection{Panelleden uit ontwikkelingslanden}

De samenstelling van panels is onder het huidige systeem onevenwichtig en is geen weerspiegeling van het lidmaatschap van de WTO. Onderdanen van enkele kleine Leden, zoals Nieuw-Zeeland en Zwitserland, zijn duidelijk oververtegenwoordigd in panels terwijl er relatief weinig onderdanen uit ontwikkelingslanden in panels zetelen. De overstap naar permanente panelleden, die volgens een rotatiesysteem en ongeacht hun nationaliteit in een panel zetelen, kan en zal daar ongetwijfeld verandering in brengen. Bij de benoeming van permanente panelleden moet het Orgaan voor Geschillenbeslechting er over waken dat de groep van permanente panelleden een goede weerspiegeling is van het lidmaatschap van de WTO. Bij de Beroepsinstantie zijn altijd drie of vier van de zeven leden uit ontwikkelingslanden afkomstig. Men mag eenzelfde verhouding verwachten in de groep van permanente panelleden.

\subsection{Kwaliteit van panelrapporten}

De overstap naar permanente panelleden zal ongetwijfeld ook de kwaliteit van de panelrapporten ten goede komen. Deze "beroepspanelleden" zullen zich, in tegenstelling tot ad hoc panelleden, volledig kunnen toeleggen op het complexe en snel evoluerende WTO recht. Permanente panelleden zullen ook snel veel meer ervaring kunnen opbouwen met feitenonderzoek en procedureproblemen. Ik betwijfel echter ten zeerste dat - zoals de Europese Unie stelt - de overstap naar permanente panelleden het aantal beroepsprocedures sterk zal doen dalen. Zoals reeds opgemerkt hebben partijen weinig te verliezen en alles te winnen door in beroep te gaan tegen een voor hen ongunstig panelrapport. Zolang dat het geval is, zal het aantal beroepsprocedures hoog blijven.

\subsection{Extra kosten}

Het huidige systeem van ad hoc panelleden is goedkoop. Panelleden die diplomaat of ambtenaar van een WTO Lid zijn, worden niet betaald. Zij ontvangen enkel reiskosten en een bescheiden onkostenvergoeding. Panelleden die niet verbonden zijn aan de overheid, zoals academici en advocaten, ontvangen een honorarium dat nu $€ 410$ per dag bedraagt en dat in vergelijking met de gangbare honoraria in internationale geschillenbeslechting laag is. Tijdens de periode van 1999 tot 2001, een periode van grote activiteit, bedroegen de kosten voor panelprocedures gemiddeld iets meer dan $€ 680,000$ per jaar en kostte één enkele panelprocedure gemiddeld $€ 39,000$ per panel. ${ }^{41}$ Het WTO geschillenbeslechtingssysteem is daarmee ongetwijfeld het goedkoopste systeem voor internationale geschillenbeslechting. De overstap naar permanente panelleden zal het WTO systeem uiteraard duurder maken. Hoeveel duurder is afhankelijk van het aantal permanente panelleden, hun voltijds of deeltijds statuut en de hoogte van hun remuneratie. De Europese Commissie heeft echter berekend dat 15 voltijdse permanente panelleden, die men naar overheidsnormen behoorlijk maar niet overdreven zou betalen, de WTO op jaarbasis iets minder dan $€ 3.7$ miljoen zou kosten. Het

41 Niet inbegrepen in deze cijfers zijn de kosten van de ondersteuning die panels ontvangen van het Secretariaat van de WTO. 
nieuwe systeem zou dus op jaarbasis $€ 3$ miljoen per jaar meer kosten dan het huidige systeem. Snellere procedures, kwalitatief betere uitspraken, meer onafhankelijkheid en onpartijdigheid, meer panelleden uit ontwikkelingslanden en, in het algemeen, meer rechtszekerheid en voorspelbaarheid in de internationale handelsrelaties zijn die extra kosten mijns inziens waard. Een cruise missile van het type Tomahawk kost tussen $€ 1.1$ en 1.2 miljoen.

\subsection{1 "Alleen-zetelend panellid"?}

Het is echter algemeen bekend dat vele WTO Leden het belangrijk vinden dat de WTO, inclusief het geschillenbeslechtingssysteem, een goedkope organisatie is en blijft. Het zal deze Leden dan misschien ook verheugen te horen dat de overstap naar permanente panelleden niet zo duur hoeft te zijn als men tenminste bereid is om een nog verdergaande hervorming van de panelprocedure te aanvaarden. Zoals vermeld wordt nu elk geschil gehoord en beslecht door een panel van drie leden. Men zou kunnen overwegen om sommige categorieën van geschillen te laten beslechten door een "alleen-zetelend panellid». Ik denk hierbij bijvoorbeeld aan geschillen die handelsmaatregelen van de overheid, zoals anti-dumping heffingen en vrijwaringsmaatregelen, betreffen. Het lijkt mij minder aangewezen om een "alleen-zetelend panellid" geschillen betreffende de wetgeving of handelingen van algemene strekking te laten beslechten. Als "alleen-zetelende panelleden" een deel van de geschillen zouden beslechten dan kan het aantal permanente panelleden worden teruggebracht tot bijvoorbeeld elf, of zelfs negen. Een ander voordeel van de invoering van "alleen-zetelende panelleden" is dat de panelprocedure normaal gesproken sneller zal kunnen worden afgehandeld dan nu het geval is. Voor geschillen betreffende bijvoorbeeld anti-dumping heffingen en vrijwaringsmaatregelen is een dergelijke snellere afhandeling zeker gewenst. Het is zeker ongewoon in internationale geschillenbeslechting om het beslechten van een geschil over te laten aan een alleen-zetelende rechter of arbiter. Binnen het WTO geschillenbeslechtingssysteem worden momenteel enkel beslissingen over de "redelijke termijn voor tenuitvoerlegging" in de zin van artikel 21.3 (c) van het Memorandum over Geschillenbeslechting genomen door een alleen-zetelende arbiter. Bij het Europees Gerecht van Eerste Aanleg kunnen bepaalde categorieën van geschillen, wanneer zij aanhangig zijn bij een kamer bestaande uit drie rechters, door de rechter-rapporteur als alleensprekende rechter worden berecht, indien zij, gelet op de geringe moeilijkheid van de gerezen rechtsvragen of feitelijke vragen, het geringe belang van de zaak en het ontbreken van andere bijzondere omstandigheden, zich daartoe lenen. ${ }^{42}$ Deze regeling zou voor de WTO een bron van inspiratie kunnen zijn.

Het lijdt geen twijfel dat een panel van drie permanente panelleden doorgaans tot beter beargumenteerde en evenwichtigere uitspraken zal komen dan een "panel" van één lid. Als echter WTO Leden de extra kosten van de overstap naar permanente panelleden willen beperken, kan worden gedacht aan de invoering van "alleen-zetelende panelleden" voor bepaalde categorieën van geschillen. Men kan de mogelijke nadelen en gevaren van rechtspraak door "alleen-zetelende panelleden" beperken door - naar analogie met iets dat nu reeds bij de Beroepsinstantie gebeurt - het "alleen-zetelend panellid" te verplichten om alvorens tot een besluit te komen in discussie te gaan met de andere permanente panelleden over de belangrijkste vragen die in het betreffende geschil rijzen. Het "alleen-zetelende

42 Artikel 14, lid 2, van het Reglement voor de procesvoering van het Gerecht, zoals gewijzigd bij besluit van het Gerecht van 17 mei 1999 met het oog op de invoering van de enkelvoudige kamer, Publicatieblad 
panellid" is als enige bevoegd om uitspraak te doen maar hij of zij gebruikt zijn of haar collega's panelleden als klankbord. Een gelijkaardig "peer advice" systeem heeft bij de Beroepsinstantie heel goed gewerkt. Zulk systeem draagt bij tot consistentie in de rechtspraak en laat toe te putten uit de individuele en collectieve ervaring en deskundigheid van alle panelleden. Ook het feit dat er beroep kan worden ingesteld tegen de uitspraak van een "alleen-zetelend panellid" - een mogelijkheid die bij andere systemen van internationale geschillenbeslechting meestal niet bestaat - maakt rechtspraak door een "alleen-zetelend panellid" gemakkelijker aanvaardbaar.

\subsection{Samenvattend}

Onder het huidige systeem zijn panels samengesteld uit ad hoc panelleden. Deze "gelegenheidspanelleden" zijn vaak diplomaten of ambtenaren van landen die niet direct bij het geschil betrokken zijn. Ad hoc panelleden doen het panelwerk naast en bovenop vaak zware beroepstaken. De Europese Unie wil de werking van panels "professionaliseren" en stelt voor een beperkte groep van permanente panelleden te benoemen. Deze overstap van ad hoc naar permanente panelleden zal leiden tot snellere procedures en kwalitatief betere panelrapporten. Bovendien zal de onafhankelijkheid en de onpartijdigheid van de permanente panelleden beter kunnen worden gewaarborgd. Tenslotte zal een overstap naar permanente panelleden leiden tot een betere vertegenwoordiging in panels van onderdanen van ontwikkelingslanden. Permanente panelleden hoeven niet noodzakelijkerwijze juristen te zijn. Het is wel belangrijk dat permanente panelleden geen deeltijds, maar een voltijds statuut krijgen. Ambtenaren en diplomaten van WTO Leden kunnen tot permanent panellid worden benoemd op voorwaarde dat zij tijdens hun mandaat alle banden met hun overheid verbreken. Een systeem met permanente panelleden is duurder dan het huidige systeem. Als die kosten een belangrijk bezwaar tegen dit nieuwe systeem zouden zijn, dan kan worden gedacht aan een beperking van het aantal permanente panelleden. Een dergelijke beperking is mogelijk als bepaalde categorieën van geschillen door een "alleen-zetelend panellid" zouden worden beslecht.

\section{Maatregelen bij niet-naleving van een uitspraak}

\subsection{Falen van het huidige mechanisme?}

Zoals vermeld beschikt het WTO geschillenbeslechtingssysteem over een uniek mechanisme om de snelle en correcte naleving van uitspraken van panels en de Beroepsinstantie te bewerkstelligen. Eind augustus $2002 \mathrm{kwam}$ dit mechanisme nog eens uitgebreid in de belangstelling toen het panel in de FSC -zaak de strafmaatregel die de Europese Unie tegen de Verenigde Staten zal mogen nemen begrootte op \$ 4 miljard per jaar. Zoals de Amerikaanse regering vorige jaar reeds stelde, is het daadwerkelijk toepassen van strafmaatregelen van deze omvang vergelijkbaar met het werpen van een atoombom op het internationaal handelssysteem. Niet alleen Amerikaanse maar ook Europese ondernemingen zouden zwaar worden getroffen. Het Europese bedrijfsleven maant dan ook aan tot uiterste voorzichtigheid en de Europese Unie heeft zich tot dusver heel terughoudend opgesteld met betrekking tot het daadwerkelijk toepassen van deze strafmaatregel.

Zoals eerder reeds vermeld, rijzen er belangrijke vragen over de effectiviteit van de maatregelen waarin het WTO geschillenbeslechtingssysteem voorziet om de naleving van 
uitspraken van panels en de Beroepsinstantie te bewerkstelligen. Met betrekking tot vrijwillige compensatie, moet worden vastgesteld dat tijdens de afgelopen acht jaar de partijen in geval van niet-naleving van de uitspraak het slechts heel zelden eens kunnen worden over vrijwillige compensatie door de verweerder. Met betrekking tot strafmaatregelen, staan vele Leden sceptisch tegenover de effectiviteit van deze maatregelen om de naleving van uitspraken te waarborgen.

Het is belangrijk om hier nog eens te herhalen dat in de meeste geschillen de tenuitvoerlegging van de uitspraak correct en tijdig gebeurt. Leden leven de uitspraken van panels en de Beroepsinstantie na omdat zij ervan overtuigd zijn dat het in hun eigenbelang is de regels van het multilateraal handelssysteem te eerbiedigen. Niettemin is het voor de geloofwaardigheid van het WTO geschillenbeslechtingssysteem belangrijk om te beschikken over een effectief mechanisme om Leden die weigeren een uitspraak ten uitvoer te leggen, hiertoe toch te bewegen.

In het kader van de Doha Ontwikkelingsronde en de onderhandelingen over de hervorming van het geschillenbeslechtingssysteem, hebben de Europese Unie, Korea, Australië, Ecuador, de Filippijnen en Thailand voorstellen gedaan ter verbetering van het WTO mechanisme om de snelle en correcte naleving van uitspraken te realiseren. Ik concentreer mij in deze rede op het meest vernieuwende voorstel, het voorstel van Ecuador. Ecuador heeft met betrekking tot deze problematiek "recht van spreken». Het was immers Ecuador dat in het kader van de Bananen-zaak moest vaststellen dat het nemen van strafmaatregelen om de Europese Unie ertoe te brengen het onrechtmatige bananeninvoerregime te veranderen, juridisch wel mocht maar economisch niet haalbaar was.

\subsection{Het voorstel van Ecuador}

Ecuador stelt voor dat wanneer een uitspraak niet tijdig wordt nageleefd, de verweerder aan de klager een compensatiepakket van handels- en andere voordelen voorstelt ten bedrage van de "schade"43 die de verweerder veroorzaakt door de voortdurende niet-naleving van de uitspraak. De omvang van de "schade" wordt, aldus het Ecuadoriaanse voorstel, bepaald op dezelfde manier en op hetzelfde tijdstip als de redelijke termijn voor de naleving van de uitspraak, d.i. door onderling akkoord tussen de partijen of door bindende arbitrage. ${ }^{44}$ Ecuador stelt voor om bij niet-naleving binnen de redelijke termijn de verweerder te verplichten de klager compensatie aan te bieden. Onder de huidige regels is de compensatie vrijwillig. Biedt de verweerder geen of te weinig compensatie in handelsvoordelen aan dan zal, volgens het Ecuadoriaanse voorstel, mogen worden verondersteld dat compensatie in contant geld wordt aangeboden. Deze compensatie dient de verweerder onmiddellijk te betalen in maandelijkse termijnen. Monetaire compensatie kan echter slechts gedurende zes maanden worden opgelegd teneinde te vermijden dat deze compensatie in plaats van een maatregel om de naleving van een uitspraak te bewerkstelligen, een soort afkoopregeling voor een schending van het WTO recht wordt. Wanneer na zes maanden de verweerder de uitspraak nog steeds niet naleeft, moeten de Leden, aldus Ecuador, overgaan tot "extreme" middelen om de beëindiging van de schending van het WTO recht te bewerkstelligen. Deze extreme middelen kunnen bestaan uit het opschorten van het recht van de verweerder om

\footnotetext{
43 De "schade" is in WTO-technische termen gesproken, het tenietdoen of de uitholling van handelsvoordelen die voortspruiten uit de WTO verdragen.

44 Zie artikel 21.3(c) van het Memorandum over Geschillenbeslechting.
} 
gebruik te maken van het geschillenbeslechtingssysteem of uit het toestaan van zeer zware strafmaatregelen.

\subsection{Verplichte compensatie}

Niemand zal betwisten dat compensatie de voorkeur verdient boven strafmaatregelen. Compensatie in de vorm van het verlenen van handelsvoordelen is handelsbevorderend terwijl strafmaatregelen in de vorm van de opschorting van handelsvoordelen handelsvernietigend is. Zoals eerder vermeld is onder de huidige regeling compensatie vrijwillig en zijn in heel weinig geschillen tot dusver klager en verweerder tot een akkoord over compensatie gekomen. Het Ecuadoriaanse voorstel om compensatie te verplichten is mijns inziens een goed idee. Men mag echter niet te veel verwachten van zulke verplichte compensatie. De ruimte waarover Leden, en in het bijzonder geïndustrialiseerde Leden, beschikken om compensatie in de vorm van handelsvoordelen aan te bieden is beperkt. De gemiddelde invoerheffingen zijn al laag en de niet-tarifaire handelsbelemmeringen zijn ofwel in strijd met het WTO recht of zijn noodzakelijk voor de bescherming van belangrijke belangen en waarden. Hoewel men perfect kan beargumenteren dat een Lid dat de schade niet kan of wil compenseren met handelsvoordelen, moet compenseren in contant geld, is het onwaarschijnlijk dat een WTO Lid dit zal doen. WTO Leden zijn mijns inziens niet bereid om aan andere Leden maandelijks miljoenen uit de schatkist te betalen als compensatie voor de niet-naleving van een uitspraak. Toegepast op de FSC-zaak zou zulke regeling betekenen dat de Verenigde Staten aan de Europese Unie maandelijks een bedrag van \$ 333 miljoen wegens de niet-naleving van de FSC-uitspraak zou moeten betalen. Het Ecuadoriaanse voorstel met betrekking tot verplichte monetaire compensatie is interessant maar niet werkzaam en maakt zeer weinig kans om door de WTO Leden aanvaard te worden.

\subsection{Extreme middelen}

Indien de verweerder de verplichte (monetaire) compensatie niet zou betalen of na zes maanden van monetaire compensatie de uitspraak nog steeds niet naleeft, wil Ecuador overgaan tot het gebruik van "extreme" middelen om de naleving van de uitspraak te bewerkstelligen. Het Ecuadoriaanse voorstel voorziet in twee "extreme" middelen.

Het eerste "extreem" middel bestaat erin een Lid het recht te ontzeggen gebruik te maken van het geschillenbeslechtingssysteem zolang dat Lid een uitspraak van een panel of de Beroepsinstantie niet naleeft. Een Europese diplomaat sprak in dit verband al van "unilaterale ontwapening" en gaf duidelijk te kennen dat de betrokken Leden dit "heel vervelend" zouden vinden. Dit lijkt mij dus een nuttig pressiemiddel om de naleving van uitspraken te bewerkstelligen. Het is echter belangrijk dat dit middel met grote omzichtigheid wordt gebruikt.

Een tweede "extreem" middel is het toestaan van zeer hoge strafmaatregelen. Hiermee worden bedoeld strafmaatregelen hoger dan de omvang van de "schade" veroorzaakt door de verweerder. Het Orgaan voor Geschillenbeslechting zou strafmaatregelen ten bedrage van de schade vermenigvuldigd met een factor $\mathrm{N}$ kunnen toestaan. Ik betwijfel echter of dit middel effectiever zal zijn dan de huidige strafmaatregelen. Het lijkt mij dat deze superstrafmaatregelen nog meer dan de huidige strafmaatregelen voor vele Leden geen realistische optie zijn. Stel dat Ecuador in de Bananen-zaak het recht zou hebben gekregen om tegen de 
Europese Unie strafmaatregelen ten bedrage van \$ 400 miljoen, in plaats van \$ 202 miljoen, te nemen, zou Ecuador dan wel strafmaatregelen hebben kunnen nemen? Bovendien zijn deze strafmaatregelen nog meer dan de huidige maatregelen handelsvernietigend. De superstrafmaatregelen zullen ook nog meer en nog zwaarder economische activiteiten en ondernemingen treffen die niets met de WTO-strijdige handelsregeling of wetgeving te maken hebben.

\subsection{Collectieve strafmaatregelen}

In het verleden is de idee geopperd om collectieve strafmaatregelen te nemen tegen Leden die een uitspraak van een panel of de Beroepsinstantie niet ten uitvoer leggen. Het nemen van strafmaatregelen zou dan niet meer worden overgelaten aan de klager maar zou een zaak worden van alle Leden. Een strafmaatregel schaadt echter ook de economie van het Lid dat de maatregel neemt. Leden die door de WTO-strijdige handelsregeling of wetgeving niet direct worden getroffen in hun handelsbelangen, zullen daarom niet erg enthousiast zijn over het nemen van strafmaatregelen. Alleen wanneer zij ervan overtuigd kunnen worden dat de nietnaleving van uitspraken het wereldhandelssysteem ondermijnt en aldus ook hun belangen schaadt, zullen Leden bereid zijn zich aan te sluiten bij collectieve strafmaatregelen. Dit lijkt mij nu nog niet het geval. Wat mij wel reeds mogelijk lijkt is ook derde partijen bij een geschil, d.i. Leden die per definitie een "wezenlijk" belang bij het geschil hebben, toe te staan om ook strafmaatregelen te nemen tegen het Lid dat nalaat een uitspraak correct ten uitvoer te leggen.

\subsection{Samenvattend}

In de meeste geschillen werden uitspraken tijdig en correct nageleefd. Slechts in enkele geschillen was dit niet het geval. In die gevallen werd het bijzondere mechanisme om de naleving van uitspraken te bewerkstelligen gebruikt. Vrijwillige compensatie lijkt echter niet te werken en hoewel men kan argumenteren dat in de Bananen-zaak de strafmaatregel van de Verenigde Staten tegen de Europese Unie heeft bijgedragen tot de uiteindelijke naleving van de uitspraak, beschouwen vele Leden de huidige regeling betreffende strafmaatregelen als onbevredigend. Verschillende Leden hebben voorstellen tot wijziging van het WTO mechanisme om de naleving van uitspraken te bewerkstelligen gedaan. Ik heb me beperkt tot een bespreking van het voorstel van Ecuador, het meest vernieuwende voorstel. Geïnspireerd door dit voorstel, ben ik van oordeel dat het WTO geschillenbeslechtingssysteem kan verbeterd worden door de verweerder bij niet-naleving van een uitspraak te verplichten compensatie aan te bieden ten bedrage van de "schade" veroorzaakt door de voortdurende niet-naleving. De omvang van die "schade" moet vooraf, bij onderling akkoord of door bindende arbitrage, worden bepaald. Eveneens meen ik dat aan een Lid het recht te ontzeggen gebruik te maken van het geschillenbeslechtingssysteem een effectief pressiemiddel kan zijn om de naleving van een uitspraak door dat Lid te bewerkstelligen. Tenslotte meen ik dat het eveneens nuttig is aan de bij een geschil betrokken derde partijen het recht toe te kennen om eveneens strafmaatregelen te nemen in geval van niet-naleving van de uitspraak in het geschil. 


\section{Waarschuwing met betrekking tot een verdere verbetering van het systeem}

Deze discussie over mogelijke verbeteringen aan het WTO geschillenbeslechtingssysteem mag ons echter niet doen vergeten dat, zoals eerder vermeld, het huidige systeem reeds effectief en daadkrachtig werkt. Hoewel een verdere verbetering van het systeem wenselijk is, schuilt er in zulke verdere verbetering een gevaar.

\subsection{Institutionele onevenwicht}

Een verdere verbetering van het geschillenbeslechtingssysteem zal dit systeem nog effectiever en daadkrachtiger maken. Dit zal het zogenoemde "institutionele onevenwicht" tussen de politieke en de rechterlijke arm van de WTO verder doen toenemen. In tegenstelling tot het geschillenbeslechtingssysteem is het politiek besluitvormingssysteem van de WTO niet effectief en daadkrachtig. Politieke besluiten over nieuwe regels of over de verduidelijking van bestaande regels moeten in de praktijk bij consensus worden genomen. ${ }^{45}$ Het bereiken van een consensus over nieuwe regels of over de verduidelijking van bestaande regels is uiteraard zeer moeilijk. Terwijl op nationaal en Europees niveau, de politieke overheid controversiële rechtspraak kan bijsturen door wetgevend op te treden, bestaat in de WTO die mogelijkheid op dit ogenblik in de praktijk niet omdat het consensusvereiste het politiek besluitvormingsproces in belangrijke mate verlamt. ${ }^{46}$ Het opmerkelijke verschil in effectiviteit en daadkracht tussen, aan de ene kant, de "rechterlijke" arm en, aan de andere kant, de "politieke" arm van de WTO ondermijnt de politieke legitimiteit en aanvaardbaarheid van het geschillenbeslechtingssysteem.

\subsection{Noodzaak het evenwicht te herstellen}

Claude Barfield van het American Enterprise Institute heeft in 2001, in een controversieel boek, voorgesteld het institutionele evenwicht tussen de politieke en de rechterlijke arm van de WTO te herstellen door de rechterlijke arm te verzwakken. ${ }^{47}$ Barfield pleit er voor geschillen over controversiële en politiek gevoelige problemen te beslechten door middel van technieken van diplomatieke geschillenbeslechting, zoals bemiddeling ("mediation") en verzoening ("conciliation"). Barfield pleit er ook voor dat wanneer een belangrijke minderheid van WTO Leden zich zou keren tegen een uitspraak van de Beroepsinstantie, er aan die uitspraak geen gevolg zou worden gegeven.

Samen met velen van mijn collega's, verzet ik mij met klem tegen elke uitholling van het WTO geschillenbeslechtingssysteem. Een terugkeer naar een meer diplomatiek geschillenbeslechtingssysteem dient enkel de politiek en economisch sterke Leden van de WTO en zal leiden tot minder zekerheid en voorspelbaarheid in de internationale handel. Het probleem van het institutionele onevenwicht binnen de WTO mag en kan niet worden opgelost door de rechterlijke arm van de WTO te verzwakken. De oplossing voor dit

45 Het WTO Verdrag voorziet in besluitvorming bij meerderheidsstemming maar van die mogelijkheid wordt in de praktijk nauwelijks gebruik gemaakt.

46 Enkel in het kader van een onderhandelingsronde lijkt besluitvorming bij consensus werkzaam omdat men zulke ronde kan afsluiten met een "package deal" waarin voor ieder iets zit. Onderhandelingsrondes worden echter slechts met lange intervallen georganiseerd en slepen jarenlang aan.

47 Barfield, C., Free Trade, Sovereignty, Democracy: The Future of the World Trade Organization (The AEI Press, 2001), 245 p. 
probleem moet gezocht worden in het versterken van de politieke arm van de WTO door een verbetering van het politiek besluitvormingsproces.

\section{Besluit}

Het WTO systeem voor het beslechten van internationale handelsgeschillen is een quasirechterlijk geschillenbeslechtingssysteem met bijzondere kenmerken. Door deze kenmerken, en vooral dan de dwingende rechtsmacht, de aard en de taak van de politieke en (quasi)rechterlijke organen van het systeem, het procesverloop en het mechanisme om de naleving van uitspraken te bewerkstelligen, onderscheidt het WTO geschillenbeslechtingssysteem zich van andere internationale geschillenbeslechtingssystemen, zoals het Internationaal Gerechtshof. Het WTO geschillenbeslechtingssysteem heeft nog steeds enkele kenmerken van een diplomatiek geschillenbeslechtingssysteem, zoals de verplichte consultaties, de rol van het Orgaan voor Geschillenbeslechting en het besloten karakter van de procedures.

Het WTO geschillenbeslechtingssysteem functioneert nu bijna acht jaar en heeft tijdens die periode effectief en daadkrachtig gefunctioneerd. Het systeem wordt veelvuldig gebruikt door zowel geïndustrialiseerde als ontwikkelingslanden. De aanhangig gemaakte geschillen betroffen soms politiek en maatschappelijk gevoelige onderwerpen zoals de bescherming van het milieu en de volksgezondheid. Een aantal geschillen kon worden beslecht door onderhandelingen tussen de partijen. Waar dit niet mogelijk was, hebben panels en de Beroepsinstantie binnen relatief korte tot zeer korte termijnen uitspraak gedaan. De meeste uitspraken van panels en de Beroepsinstantie zijn tijdig en correct ten uitvoer gelegd. Problemen met de naleving van uitspraken waren er slechts in enkele geschillen, zoals de Bananen-zaak en de Hormonen-zaak, maar de problemen in die geschillen hebben wel veel aandacht gekregen. In de aanvangsjaren van het geschillenbeslechtingssysteem werd dit systeem de parel aan de kroon van de WTO genoemd. Het systeem is nog steeds een parel aan die kroon maar na acht jaar intensief gebruik heeft die parel wat van zijn glans verloren. Acht jaar ervaring met het systeem heeft ons geleerd dat dit systeem op een flink aantal punten kan en moet worden verbeterd.

Over die verbetering van het systeem wordt momenteel door de Leden van de WTO onderhandeld in het kader van de Doha Ontwikkelingsronde. Deze onderhandelingen worden gevoerd op basis van de hervormingsvoorstellen die Leden tijdens de afgelopen maanden hebben gedaan. In deze rede heb ik mij hoofdzakelijk beperkt tot een kritische beschouwing van de twee meest vernieuwende hervormingsvoorstellen: het voorstel van de Europese Unie betreffende de samenstelling van panels en het voorstel van Ecuador betreffende maatregelen om de naleving van uitspraken te bewerkstelligen. Ik sta volledig achter het voorstel van de Europese Unie om het huidige systeem van ad hoc, "gelegenheidspanelleden", te vervangen door een systeem van permanente panelleden. De introductie van zulke "beroepspanelleden" zou zeker een verbetering voor het WTO geschillenbeslechtingssysteem betekenen. Met betrekking tot het Ecuadoriaanse voorstel, ben ik van oordeel dat bepaalde aspecten van dit voorstel tot een verbetering van het geschillenbeslechtingssysteem zouden kunnen leiden. Ik denk hierbij aan verplichte compensatie en aan het opschorten van het recht het geschillenbeslechtingsysteem te gebruiken.

Bij de aanvang van mijn rede heb ik $U$ verteld dat tot dusver de vaak hooglopende handelsruzies tussen de Europese Unie en de Verenigde Staten nooit zijn ontaard in een echte handelsoorlog. Dit is in belangrijke mate te danken aan het bestaan van een geloofwaardig en 
effectief WTO systeem voor het beslechten van handelsgeschillen. Niettemin kunnen heel wat elementen van dit systeem nog worden verbeterd. Ik heb ten aanzien van twee belangrijke elementen, namelijk de samenstelling van panels en de maatregelen te nemen bij niet-naleving van uitspraken, besproken hoe het eventueel beter kan. Of en zo ja in welke mate de WTO Leden bereid zullen zijn deze en andere elementen van het systeem verder te verbeteren, zal de toekomst uitwijzen. Ik wil echter de hoop uitspreken dat het systeem verder wordt verbeterd en dat de klok niet wordt teruggedraaid, want met een verdere verbetering van het WTO geschillenbeslechtingssysteem bouwen we, in het belang van alle landen, aan een internationale orde waarin het recht zegeviert over politieke, economische en militaire macht.

\section{Dankwoord}

Mijnheer de Rector Magnificus, dames en heren,

Ik kom uit een familie van docenten en onderwijzers. Mijn vader en grootvader waren docenten; mijn moeder was onderwijzeres. Onderwijzen zit mij in het bloed. Het is een passie. Ik aanvaard dan ook met veel plezier mijn benoeming tot het ambt van bijzonder hoogleraar Internationaal Handelsrecht aan de Universiteit Maastricht. Ik dank het College van Bestuur van deze Universiteit en het Bestuur van de Faculteit Rechtsgeleerdheid voor het vertrouwen dat zij in mij stellen. Ik dank ook van harte de twee externe leden van het College van Toezicht van de leerstoel die ik vandaag officieel aanvaard: Marco Bronckers en Pieter-Jan Kuyper. Het is echter niet alleen aan hen dat ik vandaag dank verschuldigd ben.

Het is mijn voorrecht en geluk geweest een aantal grote leermeesters te hebben gehad: Joseph Weiler aan het Europees Universitair Instituut in Firenze, John Jackson aan de University of Michigan Law School, Walter van Gerven bij het Europees Hof van Justitie in Luxemburg en Florentino Feliciano en Claus-Dieter Ehlermann bij de Beroepsinstantie van de WTO in Genève. Hen wil ik vandaag danken voor wat zij mij hebben geleerd en voor de unieke kansen die zij mij hebben geboden. Zonder hen had ik hier vandaag niet op dit spreekgestoelte gestaan.

Dat geldt ook voor de vele collega's en vrienden uit mijn Antwerpse, Parijse, Florentijnse, Brusselse, Amerikaanse, Luxemburgse, Maastrichtse en Geneefse periodes. Ik dank hen allen voor hun steun en vriendschap in soms donkere tijden van lange dagen en korte nachten. Ik dank in het bijzonder mijn collega's bij de Beroepsinstantie en de Juridische Dienst van de WTO. Ik dank ook mijn Maastrichtse collega's, vooral dan mijn collega's binnen de capaciteitsgroep Internationaal en Europees Recht. Het is dankzij jullie dat mijn terugkeer naar Maastricht voor mij zo bevredigend is verlopen. Men heeft mij dit afgelopen jaar menigmaal gevraagd of ik nog geen spijt had dat ik een kantoor met een uitzicht op het Meer van Genève en de Mont Blanc had omgeruild voor een kamer met uitzicht op de tuin en de parking van de juridische faculteit. Om eerlijk te zijn, ja. Ik heb spijt gehad en heb nog steeds spijt van die verandering van werkplek ... maar ik heb nog geen moment spijt gehad van de verandering van werk. Dit is ongetwijfeld ook in belangrijke mate te danken aan de Maastrichtse rechtenstudenten, die zoals zij eerder dit jaar in de finale van de European Law Moot Court wedstrijd nog eens hebben bewezen, tot de allerbeste in Europa behoren.

Tot slot, een woord van dank voor diegenen die mij het dierbaarste zijn. Mijn ouders wil ik bedanken voor de waarden die zij mij hebben meegegeven en voor de wijze waarop zij mij gedurende zovele jaren hebben voorbereid op deze dag. Ik hoop dat zij deze dag ook een 
beetje als hun dag zien. Dat hoop ik ook voor Astrid, Thomas en Patricia. Astrid en Thomas, jullie zijn mijn lichtbaken en jij, Patricia, mijn thuishaven. Zonder jullie zou ik doelloos zwalpen op de woelige zee van het leven. Het is dan ook aan jullie dat ik deze rede opdraag.

Ik heb gezegd. 